
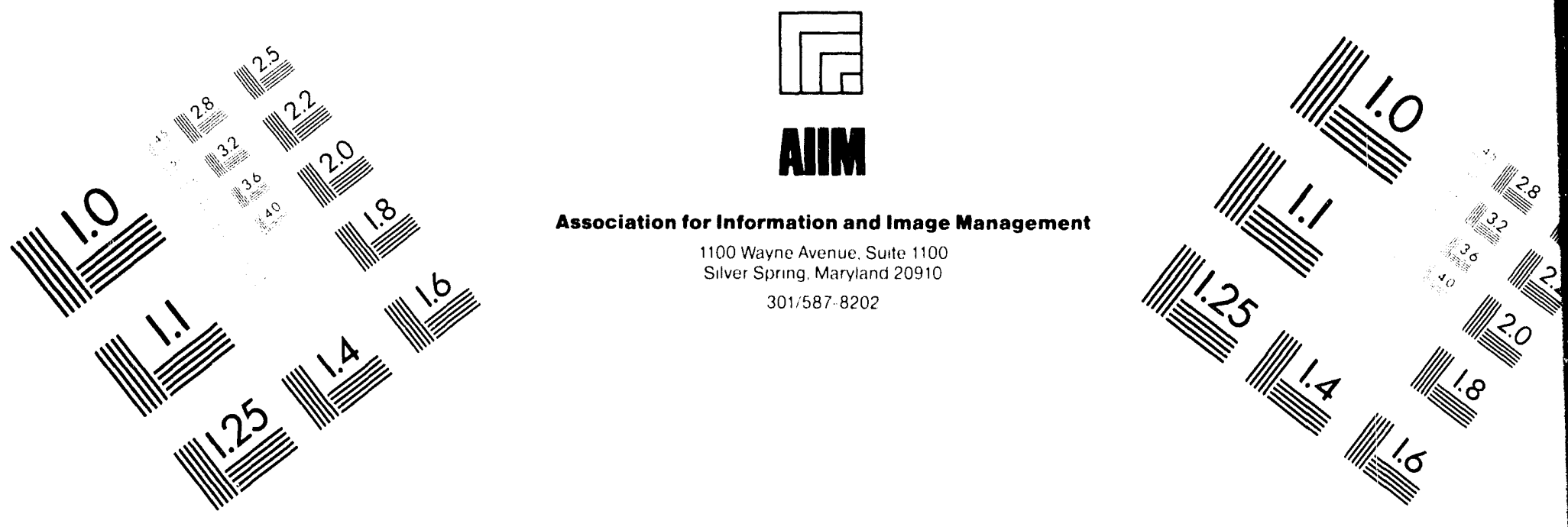

Centimeter

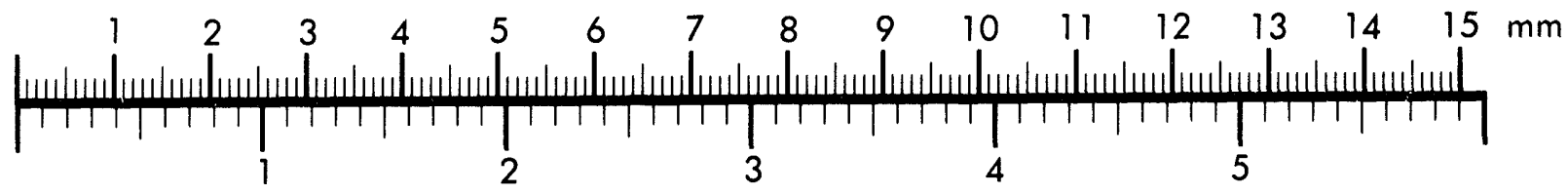
Inches
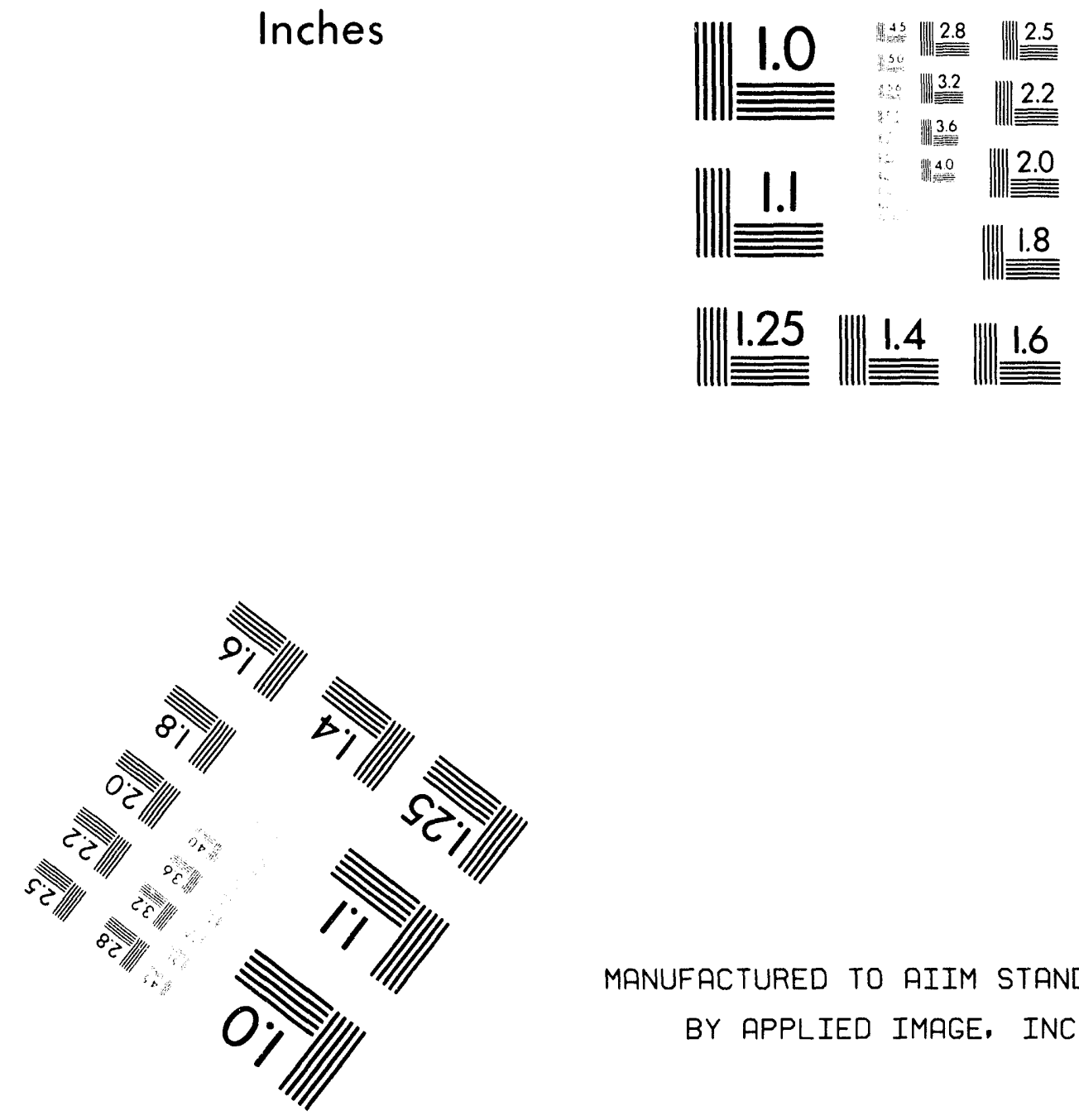

MANUFACTURED TO AIIM STANDARDS BY APPLIED IMAGE, INC.

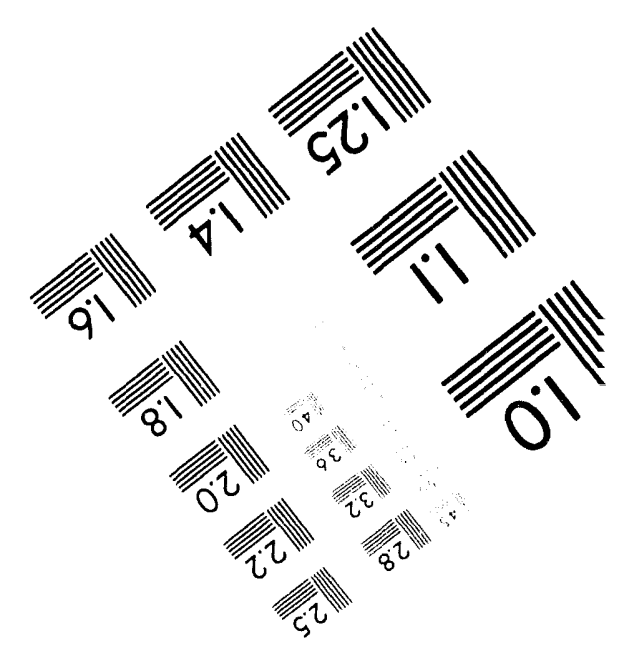



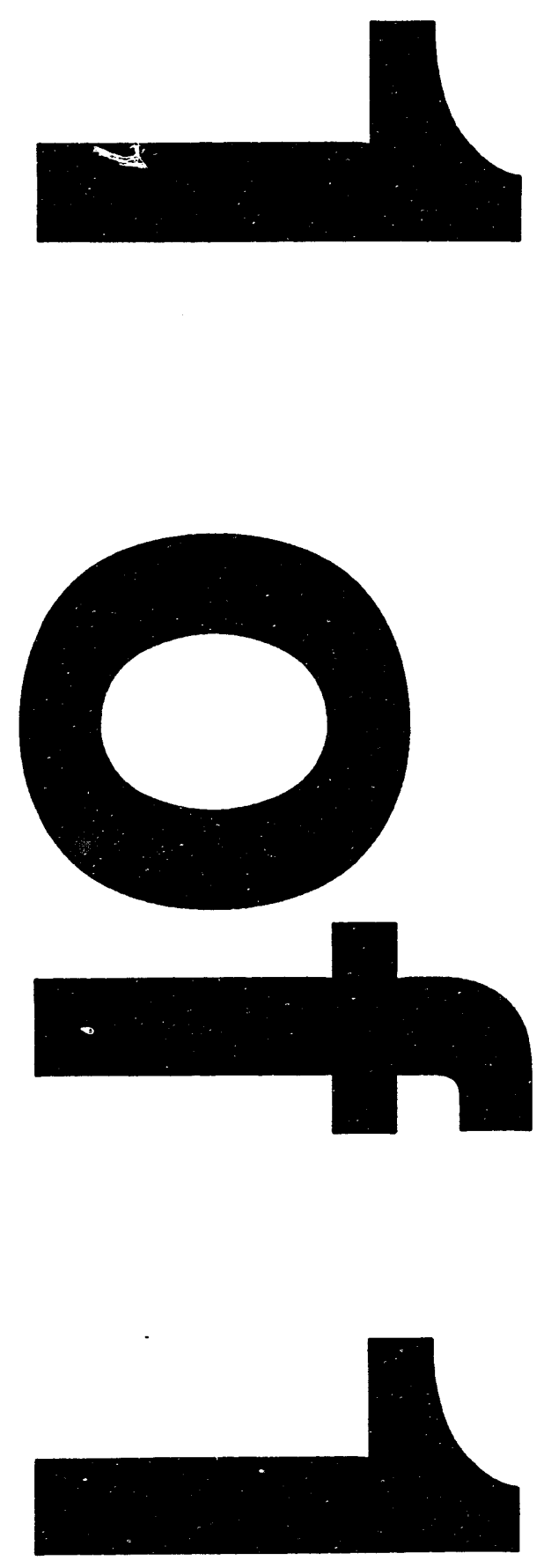


\title{
Surrogate Formulations for Thermal Treatment of Low-Level Mixed \\ Waste, Part III: Plasma \\ Hearth Process Testing
}

TTP: OR-1320-15

B\&R Code: EW4020

\author{
J. M. Chiang \\ W. D. Bostick \\ D. P. Hoffmann \\ W. H. Hermes \\ L. V. Gibson, Jr. \\ A. A. Richmond \\ Martin Marietta Energy Systems, Inc. \\ Oak Ridge, Tennessee
}

January 1994

Prepared by

OAK RIDGE K-25 SITE

and

OAK RIDGE NATIONAL LABORATORY

Oak Ridge, Tennessee 37831-7101

managed by

MARTIN MARIETTA ENERGY SYSTEMS, INC.

for the

U.S. DEPARTMENT OF ENERGY

under contract DE-AC05-84OR21400 


\section{CONTENTS}

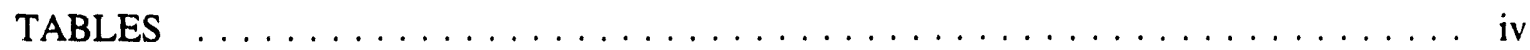

ABBREVIATIONS AND ACRONYMS $\ldots \ldots \ldots \ldots \ldots \ldots \ldots$

ACKNOWLEDGMENTS $\ldots \ldots \ldots \ldots \ldots \ldots \ldots \ldots \ldots \ldots \ldots$ vii

EXECUTIVE SUMMARY $\ldots \ldots \ldots \ldots \ldots \ldots \ldots \ldots \ldots \ldots \ldots \ldots \ldots$ ix

1. INTRODUCTION $\ldots \ldots \ldots \ldots \ldots \ldots \ldots \ldots \ldots \ldots \ldots \ldots \ldots \ldots$

2. SURROGATE SELECTION RATIONALE $\ldots \ldots \ldots \ldots \ldots \ldots \ldots \ldots \ldots \ldots \ldots$

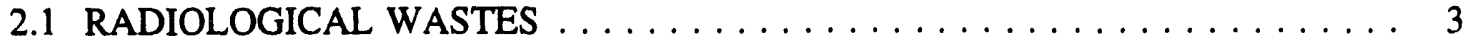

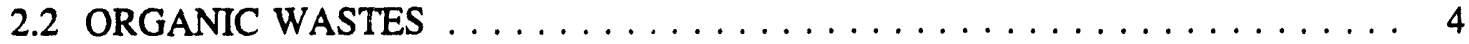

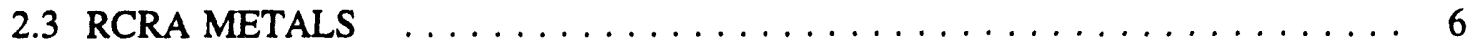

2.4 BULK COMPONENT SELECTION $\ldots \ldots \ldots \ldots \ldots \ldots \ldots \ldots \ldots \ldots$

2.5 CAVEAT/LIMITATION OF SURROGATE APPLICATION $\ldots \ldots \ldots \ldots \ldots 7$

3. WASTE SURROGATE RECIPES FOR THE PHP $\ldots \ldots \ldots \ldots \ldots \ldots \ldots \ldots \ldots$

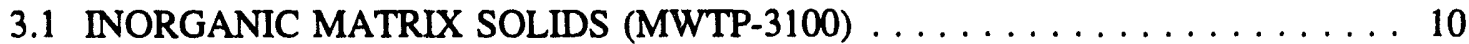

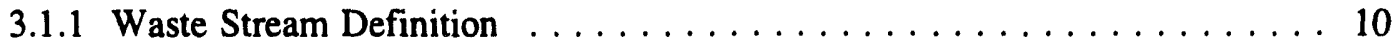

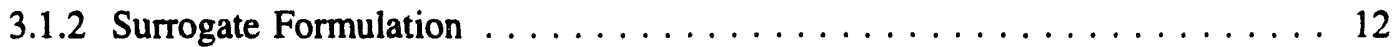

3.1 .3 Mixing Suggestion $\ldots \ldots \ldots \ldots \ldots \ldots \ldots \ldots \ldots \ldots \ldots$

3.2 HIGH ORGANIC CONTENT SLUDGES (MWTP-3122) . . . . . . . . . . 13

3.2.1 Waste Stream Definition . . . . . . . . . . . . . . . . . . . . . 13

3.2 .2 Surrogate Formulation $\ldots \ldots \ldots \ldots \ldots \ldots \ldots \ldots \ldots \ldots$

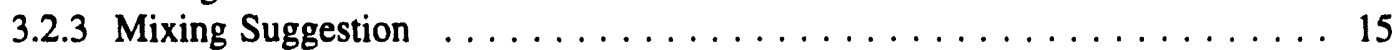

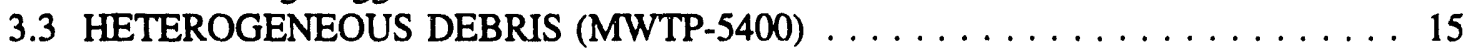

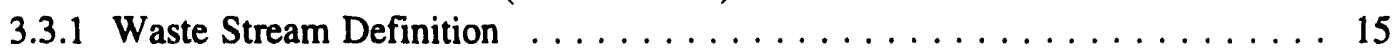

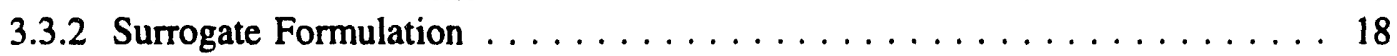

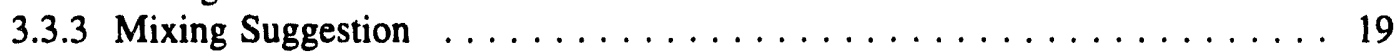

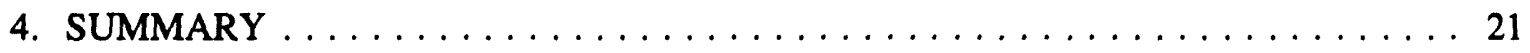

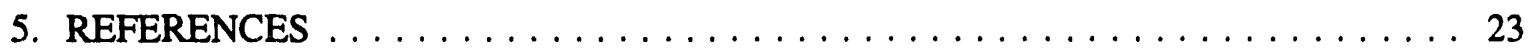




\section{TABLES}

Table

Page

1 Suggested surrogates for selected radioisotopes $\ldots \ldots \ldots \ldots \ldots \ldots \ldots$

2 Hazardous organics and potential surrogates $\ldots \ldots \ldots \ldots \ldots \ldots \ldots \ldots \ldots \ldots$

3 EPA 40 CFR, Part 261, Appendix VIII Thermal Stability Classes . . . . . . . . 6

4 Simulated inorganic sludge $\ldots \ldots \ldots \ldots \ldots \ldots \ldots \ldots \ldots \ldots \ldots \ldots$

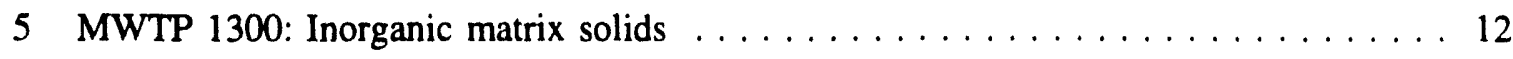

6 MWTP 3100: Inorganic matrix solids $\ldots \ldots \ldots \ldots \ldots \ldots \ldots \ldots \ldots \ldots \ldots$

7 MWTP 3122: High organic content sludges $\ldots \ldots \ldots \ldots \ldots \ldots \ldots \ldots$

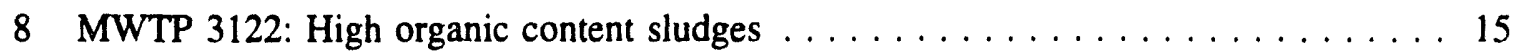

9 Simulated heterogeneous, predominantly combustible waste compositions . . . . . 17

10 MWTP 5400: Heterogeneous debris $\ldots \ldots \ldots \ldots \ldots \ldots \ldots \ldots \ldots$

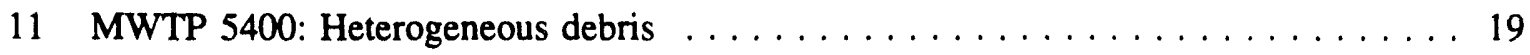




\section{ABBREVIATIONS AND ACRONYMS}

$\begin{array}{ll}\text { Ce } & \text { cerium } \\ \text { CPCF } & \text { Central Pollution Control Facility } \\ \text { DOE } & \text { Department of Energy } \\ \text { DRE } & \text { Destruction and Removal Efficiency } \\ \text { EPA } & \text { Environmental Protection Agency } \\ \text { FFCA } & \text { Federal Facility Compliance Act } \\ \text { INEL } & \text { Idaho National Engineering Laboratory } \\ \text { LANL } & \text { Los Alamos National Laboratory } \\ \text { LDR } & \text { Land Disposal Restriction } \\ \text { LLMW } & \text { low-level mixed wastes } \\ \text { MWIP } & \text { Mixed Waste Integrated Program } \\ \text { MWTP } & \text { Mixed Waste Treatment Project } \\ \text { NIOSH } & \text { National Institute for Occupational Safety and Health } \\ \text { NRC } & \text { Nuclear Regulatory Commission } \\ \text { OSHA } & \text { Occupational Safety and Health Administration } \\ \text { PCBs } & \text { polychlorinated biphenyls } \\ \text { PHP } & \text { Plasma Hearth Process } \\ \text { PHP } & \text { plasma hearth process } \\ \text { POHC } & \text { Principal Organic Hazardous Constituent } \\ \text { Pu } & \text { plutonium } \\ \text { RCRA } & \text { Resource Conservation and Recovery Act } \\ \text { RDDT\&E } & \text { Research Development Demonstration Testing and Evaluation } \\ \text { RFP } & \text { Rocky Flats Plant } \\ \text { SAIC } & \text { Science Applications International Corporation } \\ \text { TRU } & \text { transuranic } \\ \text { TSCA } & \text { Toxic Substances Control Act } \\ \text { PVC } & \text { Polyvinyl chloride } \\ & \end{array}$




\section{ACKNOWLEDGMENTS}

We wish to thank members of the Mixed Waste Treatment Project for providing the mixed waste stream classification system and for their help in identifying waste stream priorities for surrogate formulation. Members of the Mixed Waste Integrated Program and their associates provided insight into the waste stream definition and probable matrix constituents. These colleagues include B. C. Musgrave (formerly of Lawrence Livermore National Laboratory); L. Borduin, W. H. McCulla, and R. Nakaoka (Los Alamos National Laboratory); J. B. Berry (Oak Ridge National Laboratory); C. H. Brown (Los Alamos Technology Office-Rocky Flats); D. A. Hutchins (Martin Marietta Energy Systems, Inc.); O. L. Kruger (Westinghouse Hanford); W. A. Ross (Pacific Northwest Laboratory); N. French (Sandia National Laboratory); R. Geimer, R. Gillins, and J. Mayberry (SAIC, Inc.); T. D. Kirkpatrick, D. M. Ahmed, R. L. Black, and B. A. Heath (EG\&G, Idaho); and J. Vavruska (Equinox, Ltd.). We would also like to thank the following for their technical review and comments: T. C. Ho (Lamar University); R. Bastian, J. Cudahy, C. Henke, and A. Eicher (Focus Environmental, Inc.); G. Reed, T. Miller, and W. Davis (University of Tennessee). 


\section{EXECUTIVE SUMMARY}

The Plasma Hearth Process (PHP) presented in this report has been tested at a facility at Ukiah, California, in a cooperative effort between the Department of Energy (DOE), Science Applications International Corporation, Inc., and ReTech, Inc. The electrically heated plasma gas is used to destroy organic materials and bind radionuclides and Resource Conservation and Recovery Act (RCRA) metals in the glassy slag. Proof-of-principle tests were conducted successfully using nonhazardous and non-radioactive materials placed in 30-gal steel drums. Online analyses of the gaseous effluents indicated complete combustion; emissions of $\mathrm{CO}, \mathrm{NOx}$, and particulates were low. The process also produced highly stable solid waste forms.

The experiments for the next phase have been planned employing surrogates for the hazardous and radioactive components of the simulated waste streams. For cost and regulatory considerations, surrogates are utilized in the experiments to simulate or represent the radioactive and hazardous components present in the waste matrices. Designated for experiments are three representative simulated waste streams-inorganic sludge (DOE waste code no. 3100), high organic content sludge (no. 3122), and heterogeneous debris (no. 5400). Natural cerium oxide is selected to simulate the behavior of radioactive actinide and transuranium elements, while natural cesium chloride is simulated for the study of relatively volatile radioactive fission products. For RCRA organics, naphthalene and 1,2-dichlorobenzene are semivolatile compounds selected to represent significant challenges to thermal destruction, whereas chlorobenzene is selected for the study of relatively volatile organics. Salts of chromium, nickel, lead, and cadmium are chosen to represent the twelve regulated toxic metals for emission and partitioning studies. The ingredients in the bulk (innocuous) matrix in each waste category are mimics of the real waste stream.

A companion report, describes surrogates for a number of other priority waste stream categories that should be amenable to treatment by a robust melter technology such as the PHP. These technologies are expected to have inherent advantages in processing inorganic residuals. The companion report presents surrogate formulations for some of these candidate waste streams including, Ash (3110); Cement sludges, Ashes, and Solids (3140); Heterogenous Debris (5400); Lab Packs (6100); and Lead Shapes (7200).

In addition, two companion reports, the benchmarking of thermal treatment technologies and the data quality objectives for the thermal treatment systems, can provide a documented approach toward an unbiased evaluation of the PHP technology. Utilizing the consistent method of process and system evaluations and performance test procedures promulgated in these reports, in conjunction with consistent simulated waste stream compositions, will allow enhanced comparison of the PHP as versus other thermal treatment technologies. 


\section{INTRODUCTION}

The U. S. Department of Energy (DOE) managed facilities are estimated to have a current inventory of $590,000 \mathrm{~m}^{3}$ of mixed wastes, of which $42 \%$, or $247,000 \mathrm{~m}^{3}$, is reported to be that of low-level mixed wastes (LLMW), the primary focus of this report, with the balance being highlevel and transuranic (TRU) mixed wastes. Moreover, an additional $298,000 \mathrm{~m}^{3}$ of mixed wastes is estimated to be generated during the next 5 years. The wastes are stored and generated at 50 sites across the DOE Complex in 22 states, while most of the LLMW, $-79 \%$, are being stored in 3 sites; namely, Rocky Flats Plant (RFP), the Oak Ridge K-25 Site, and Idaho National Engineering Laboratory (INEL). ${ }^{1,2}$

The Land Disposal Restriction (LDR) ${ }^{3}$ standards set by the Environmental Protection Agency (EPA) prohibits land disposal and storage of untreated hazardous waste which affects most of the above mentioned mixed wastes. There is insufficient treatment capacity, and in many cases no treatment technology, to treat DOE's mixed wastes to the LDR standards. In May 1992, a temporary compliance was granted for mixed waste per Federal Facility Cornpliance Act (FFCA), based on insufficient treatment capacity. Under the requirements of FFCA, all federal facilities must waive sovereign immunity and come into compliance with applicable federal and state laws and regulations. The FFCA also requires submission of site-specific mixed waste treatment plans to the appropriate regulatory agency, including schedules for developing treatment capability and capacity.

Facing such pressing regulatory compliance requirements, DOE and its contractors are working together expeditiously to upgrade and expand the existing treatment facilities, and many new processes and technologies are being evaluated for their potential application. The development and implementation of the treatment processes may involve some evolving or emerging technologies and others which have been employed in the private industry but may require modifications for handling mixed waste. Such an open-ended all-inclusive cocperative effort will involve contributions of knowledge, experience, and expertise from government, academia, and private sectors. The treatment and disposal needs are generally being addressed through a combination of site-specific and cross-complex technology development activities, and consideration is given to the development of processes or technologies capable of treating multiple waste streams with minimal pretreatment requirements.

The purpose of this report is to define the waste feed surrogate formulations for the plasma hearth process (PHP), one of a host of new technology demonstrations funded by DOE. This technology is being tested and evaluated at a facility at Ukiah, California, in a cooperative effort between Science Applications International Corporation (SAIC), Inc., and ReTech, Inc. There are a few other plasma arc pilot facilities in the U.S. and abroad. The electrically heated plasma gas is used to destroy organic materials and bind radionuclides and Resource Recovery and Conservation Act (RCRA) metals in the glassy slag. Nonradioactive and nonhazardous materials have been employed for proof-of-principle testings with promising results. For the planned next phase of experimentation, appropriately selected surrogate materials for radionuclides are to be formulated in the test batches. Surrogate recipes for the designated mixed waste streams are presented in the subsequent section. 


\section{SURROGATE SELECTION RATIONALE}

\subsection{RADIOLOGICAL WASTES}

The use of actual radioactive material imposes considerable restrictions on material handling, transportation, and performance testing. In addition to obtaining the requisite Nuclear Regulatory Commission (NRC) licenses to handle the appropriate radioisotopes, there are additional stringent requirements for radiological work, including personnel protective clothing, criticality safety review, emissions monitoring and reporting, and so forth. There is also a major investment in equipment that may require extensive decontamination after use. For these and other cunsiderations, it may be desirable to use simulated waste formulations that use surrogate materials to represent the expected behavior of the radiological constituents. In selecting a metal surrogate, the object is to mimic as closely as possible, but in a conservative manner, the behavior of the actual metal as incorporated into both the raw waste and the anticipated treatment residues. A companion document ${ }^{4}$ reviews the selection of surrogate materials for radiological components for testing in thermal treatment systems. Recommendations are summarized in Table 1; some of the recommendations for non-thermal systems are taken from Ref. ${ }^{5}$ For example, the lanthanide series of elements are formed by successive filling of the inner $4 \mathrm{f}$ electron orbitals, whereas the actinides are formed by filling the 5 f orbitals; thus, cerium compounds (rare earth lanthanide series) serve as reasonably good chemical and thermal surrogates for both uranium (actinide series) and plutonium (TRU series). However, there are always limitations to the use of surrogates; as Shapiro and coworkers ${ }^{6}$ report on the selection of cerium (Ce) as a surrogate for plutonium (Pu): (1) Ce exhibits a similar chemistry in that much of its aqueous solution chemistry is similar to that of $\mathrm{Pu}$, (2) Ce exhibits a different oxidation state than $\mathrm{Pu}$ so that it is not directly analogous, (3) Ce has the potential to form the strongly oxidizing ceric ion, which can enhance corrosion; (4) however, they conclude that although some of cerium's atomic characteristics do not perfectly match those of $\mathrm{Pu}$, they are closer than other available surrogates.

Table 1. Suggested surrogates for selected radioisotopes [from Ref. 7]

\begin{tabular}{lll}
\hline & \multicolumn{2}{c}{ Suggested surrogate(s) } \\
\hline Radioisotope & Thermal System & Non-thermal System \\
U-238/U-235 & $\mathrm{Ce}, \mathrm{RE}^{1}$ & $\mathrm{Ce}, \mathrm{RE}, \mathrm{Zr}, \mathrm{Mo}$ \\
$\mathrm{Pu}-239 / \mathrm{TRU}^{2}$ & $\mathrm{Ce}, \mathrm{RE}$ & $\mathrm{Ce}, \mathrm{RE}, \mathrm{Zr}$ \\
$\mathrm{Tc}-99, \mathrm{Ru}-103$ & $\mathrm{Ru}$ & $\mathrm{Ru}, \mathrm{Re}, \mathrm{Mo}, \mathrm{Mn}$ \\
$\mathrm{Cs}-137$ & Natural Cs & Natural Cs \\
$\mathrm{Sr}-90$ & Natural Sr & Natural Sr \\
\hline \multicolumn{2}{c}{${ }^{\circ} \mathrm{RE}=$ rare earth element (lanthanide series) } & \\
${ }^{\circ} \mathrm{TRU}=$ transuranic element (e.g., Np, Am)
\end{tabular}

Similarly Bates ${ }^{7}$ discussed possible surrogates for uranium, plutonium, and americium, concluding that " While there are no perfect surrogates for these radionuclides, cerium is generally the most conservative (best simulates their behavior). Other less conservative surrogates of plutonium, in degree of similarity. are neodymium $>$ lanthanum $>$ praseodymium $>$ gadolinium $>$ ytterbium $>$ dysprosium $>$ erbium $>$ europium $>$ terbium $>$ lutetium $>$ samarium." 
According to those arguments, it would appear that cerium compounds represent conservative surrogates for both $\mathrm{U}$ and $\mathrm{Pu}$, which are the two most frequently encountered radiological contaminants expected in the DOE waste streams. Bates ${ }^{7}$ has recommended the use of $-0.5 \mathrm{wt} \%$ $\mathrm{Ce}_{2} \mathrm{O}_{3}$ to ensure an adequate level of surrogate for easy detectability in the waste form or residues. A companion document ${ }^{4}$ has shown that the thermal behavior of $\mathrm{CeO}_{2}$ and $\mathrm{Ce}_{2} \mathrm{O}_{3}$ are very similar and that their solubilities are similar and hence due to economic consideration the use of $\mathrm{CeO}_{2}$ is being suggested for use in the surrogate formulations. For nonthermal applications, the more soluble $\mathrm{CeCl}_{3}$ salt is recommended (to challenge leachability testing criterion).

In addition to the major fuel and defense isotopes (i.e., U-235/238, Pu-239) the major nuclear fuel fission products (e.g., Cs-137, Tc-99, Sr-90) have to also be addressed. The fission products tend to have greater volatility than the parent actinide ${ }^{7}$ and hence require an additional surrogate material to ensure that the lower volatility radiological materials can be tested. Of the three fission products listed technetium does not have any stable isotopes and hence is not a candidate material for the surrogate waste stream formulations. Both cesium and strontium have stable isotopes and could be used in the surrogate waste stream formulations. Natural Cs is a good nonradioactive marker that will be used for the relatively volatile fission products.

\subsection{ORGANIC WASTES}

Many of DOE's radiological wastes are contaminated with hazardous organic residues, especially waste water treatment sludges and spent sorbent materials. Typical residues include degreasing solvents (e.g., tri- and tetrachloroethylene, methyl ethyl ketone, acetone), waste oils, and material contaminated with polychlorinated biphenyls (PCBs). Table 2 lists several of the hazardous organic compounds regulated under the EPA RCRA (RCRA; 40 CFR, Part 261, Appendix VIII) and the Toxic Substances Control Act (TSCA). The Table also lists an Incineration Ranking designation (8) [based on the concept of thermal stability under low oxygen, post flame conditions] for several of the organic compounds of regulatory concern. The Incineration Index is a relative measure of the degree of difficulty for a waste constituent to be thermally destroyed; a low value for the index ranking indicates that the compound is relatively refractory (i.e., stable) toward thermal destruction. Table 3 describes the seven classes that have been identified for thermal stability ranges; the designation $\mathrm{T}_{99(2)}$ indicates that $99 \%$ destruction will be achieved within a $2-\mathrm{sec}$ residence time in the indicated temperature range.

Under EPA protocol, an incinerator facility must achieve a Destruction and Removal Efficiency (DRE) of $99.99 \%$ for each Principal Organic Hazardous Constituent (POHC) designated for each waste feed. The selection of POHCs for trial burn evaluation is based upon the relative difficulty of incinerating the waste; the premise is that if the DRE requirement is met for the most-difficult-to-incinerate compounds during a trial burn, then other compounds should be successfully destroyed in subsequent routine operation. ${ }^{8}$

For selection of a POHC for addition to a surrogate waste package for thermal treatment testing, desirable properties include a relatively low incinerability index (e.g., Class 1 in Table 3), to provide some assurance that other compounds of concern will also have high DREs, and a low ambient temperature apor pressure, to minimize loss of POHC by fugitive emission during surrogate formulation and handling. ${ }^{9}$ Since there is no basis for choosing a non-hazardous surrogate material for the hazardous organic constituent a selection has to be made which both challenges the thermal system and does not create excessive risks and secondary waste stream generation burdens during the preparation of the surrogate waste stream formulation. 
Table 2. Hazardous organics and potential surrogates

\begin{tabular}{|c|c|c|c|}
\hline Compounds & EPA waste code & $\begin{array}{c}\text { Incinerability } \\
\text { ranking }\end{array}$ & $\begin{array}{c}\text { Vapor pressure } \\
\left(\mathrm{mm} \mathrm{Hg} @ 25^{\circ} \mathrm{C}\right)\end{array}$ \\
\hline Benzene & D018 & 3 & 94.2 \\
\hline Naphthalene & & 5 & 0.05 \\
\hline Chlorobenzene & D021 & 18 & 11.5 \\
\hline 1,4-Dichlorobenzene & D027/F002 & $21-22$ & 1.9 \\
\hline 1,2-Dichlorobenzene & D028/F002 & $23-25$ & 1.4 \\
\hline 1,2,4-trichlorobenzene & & $27-28$ & 0.43 \\
\hline Hexachlorobenzene & D032 & 31 & 0.07 \\
\hline $2,3,7,8-\mathrm{TCDD}^{b}$ & & 34 & \\
\hline Toluene & F005 & 35 & 28.0 \\
\hline Tetrachloroethylene & D039/F001,2 & 36 & 18.5 \\
\hline Trichloroethylene & D040/F001,2 & 41 & 62.5 \\
\hline Vinyl Chloride & D043 & $60-64$ & (760.) \\
\hline Phenol & & $101-102$ & 0.21 \\
\hline Cresol(s) & D026/F004 & $103-105$ & $0.1-0.4$ \\
\hline 2,4-Dimethylphenol & F003 & $108-111$ & 0.15 \\
\hline Methyl ethyl ketone & D035/F003,5 & $108-111$ & 113 \\
\hline 2,4,5-Trichlorophenol & D041 & $121-125$ & 0.04 \\
\hline 2,4,6-Trichlorophenol & D042 & $121-125$ & 0.03 \\
\hline Carbon Tetrachloride & D019/F001 & $136-140$ & 109 \\
\hline Pentachlorophenol & D037 & $151-53$ & 0.001 \\
\hline Heptachlor & D031 & $179-180$ & \\
\hline Chloroform & D022 & $194-196$ & 192 \\
\hline 1,1,1-Trichloroethane & F001,2 & 201 & 123 \\
\hline Chlordane & D020 & 221 & \\
\hline Cyclohexanone & F003 & NR & 4.5 \\
\hline Ethyl acetate & F003 & NR & 90 \\
\hline Methanol & F003 & NR & 121 \\
\hline Ethyl benzene & F003 & NR & 9.5 \\
\hline 2-Ethoxyethanol & F005 & NR & \\
\hline Isobutanol & F005 & NR & 12.3 \\
\hline Xylene(s) & F003 & NR & $6.6-8.7$ \\
\hline 2-Nitropropane & F005 & NR & 16.6 \\
\hline PCB (Aroclor 1254) & (TSCA) & NR & 0.0002 \\
\hline Methyl isobutyl ketone & F003 & NR & 7.1 \\
\hline
\end{tabular}

${ }^{a}$ C. C. Lee et al., "Incinerability Ranking Systems for RCRA Hazardous Constituents," Hazardous Waste and Hazardous Materials, 7(4) 1990. [Note: the lower the numerical rating, the more refractory the compound is towards thermal destruction.] Compounds designated "NR" are not ranked in this reference.

${ }^{b} 2,3,7,8-\mathrm{TCDD}=2,3,7,8$-Tetrachlorodibenzo-p-dioxin. 
To meet all of these criteria, three RCRA organics have been chosen to formulate the RCRA hazardous components of the surrogate waste stream formulations. Naphthalene, a semivolatile organic, (incinerability ranking 5) is a good choice by these criteria; naphthalene has been used as a destruction testing surrogate for the more toxic and carcinogenic polyaromatic hydrocarbon compounds. ${ }^{10}$ Other suitable choices include 1,2,4,5-tetrachlorobenzene (incinerability ranking 27-28) and 1,2-dichlorobenzene (incinerability ranking 23-25), which were recommended as principal surrogates for PCBs in wastes for incinerability testing. " [Note in Table 3 that many compounds of concern, including PCBs, have not yet been assigned an Incinerability Ranking]. 1,2-dichlorobenzene, which is a class 1 semivolatile organic, presents it self as a good candidate for a member of the RCRA hazardous organic constituents. One of the highest ranked (i.e. class 1) relatively volatile organics is chlorobenzene. Chlorobenzene will allow the effect of volatile organics to be tested as well as challenge the thermal system. Thus, to minimize the complexity of the surrogate waste stream formulation and to challenge the thermal treatment system for both semivolatile and volatile organics, the selection of naphthalene, 1,2-dichlorobenzene, and chlorobenzene have been selected to represent the RCRA hazardous organic constituents in the surrogate waste stream formulation.

Table 3. EPA 40 CFR, Part 261, Appendix VIII Thermal Stability Classes

\begin{tabular}{ccc}
\hline & \multicolumn{2}{c}{$\mathrm{T}_{99(2)}$} \\
\cline { 2 - 3 } Class $^{b}$ & Compound Ranking & Temperature Range, ${ }^{\circ} \mathrm{C}$ \\
\hline 1 & $1-34$ & $1590-900$ \\
2 & $35-77$ & $895-800$ \\
3 & $78-119$ & $790-705$ \\
4 & $120-193$ & $695-604$ \\
5 & $194-252$ & $600-425$ \\
6 & $253-271$ & $415-360$ \\
7 & $272-320$ & $320-100$ \\
\hline
\end{tabular}

The designation $\mathrm{T}_{99(2)}$ indicates that $99 \%$ destruction will be achieved within a 2-sec residence time in the indicated temperature range.

${ }^{\text {bC }}$. C. Lee et al., "Incinerability Ranking Systems for RCRA Hazardous Constituents," Hazardous Waste and Hazardous Materials, 7(4) 1990.

\subsection{RCRA METALS}

The EPA has identified 12 toxic metals in Appendix VIII of 40 CFR, Part 261, that pose a potential hazard to human health and the environment; these metals are: arsenic, beryllium, cadmium, hexavalent chromium, nickel, antimony, barium, lead, mercury, selenium, silver, and thallium. The EPA has determined that the risks from the burning of metal-bearing hazardous wastes in incinerators can be unacceptable under reasonable worst-case circumstances, as defined by concentrations of metals in the incinerated waste, incinerator capacity or feed rate, partitioning of metals to bottom ash, collection efficiency of emission control equipment, and local terrain and meteorological conditions. Control of metals emission is mandated under current and pending regulations [see, e.g., Section 3005(c)(3) and Part 264, Subpart O, of the RCRA regulations]. At present, toxic metals emissions from incinerators are controlled indirectly by a limitation on particulate matter. Risk-based emissions limits for individual toxic metals are proposed in addition to the existing particulate standard. 
To assess the performance of alternate treatment technologies against the applicable regulatory requirements, the regulated metals will then have to be spiked into the waste feed to enable the determination of their partitioning to various exit pathways (e.g., combustion chamber bottom ash and residual slag, air pollution control system residues, and stack emissions. ${ }^{12.13} \mathrm{~A}$ "Trial Burn Manual for the Testing of Metals" is currently being drafted to provide guidance to operating faciiities preparing to perform trial burn testing for facility permitting. ${ }^{13}$

For cost and regulatory considerations, some relatively innocuous metals may be substituted for toxic constituents in initial performance assessments as suggested in a recent report, ${ }^{14}$ in which it states, "Because metals volatility dominates partitioning, surrogates can be used and the choice of surrogates is simplified... . These results show that surrogates partition in the same manner as selected hazardous constituent metals. Thus, the use of surrogates deserves consideration, if not in aciual trial burns, then at least in scoping tests used to guide the formal trial burn." The cited report concluded that bismuth behavior in an incineration process is quite similar to that of cadmium; that magnesium or strontium is similar to that of chromium; and that copper is similar to that of arsenic, barium, and lead. It further suggested that other potential surrogates can be similarly identified based on equilibrium, vapor pressure, and temperature calculations.

Since the test facility at Ukiah, California, is permitted to handle RCRA wastes snder treatability study rule limitations, it will not be necessary to substitute for the RCRA-reculated toxic metals. In order to allow adequate analytical sensitivity for accurate determination of mass balances, the synthetic wastes will be formulated to contain $-2500 \mu \mathrm{g} / \mathrm{g}$ each of the chloride or nitrate salts, or oxides, of the following toxic metals: $\mathrm{Pb}, \mathrm{Cr}, \mathrm{Ni}$, and $\mathrm{Cd}$.

\subsection{BULK COMPONENT SELECTION}

The bulk compositions as listed are determined by "round-up" of the major innocuous chemicals present in various mixed sludge wastes, real as well as simulated. The bulk ingredients are presumably all nonregulated chemicals which are assembled in an attempt to maximize the resemblance to the nonhazardous components of a typical waste stream. Selection rationales for bulk components of each of the three simulated waste streams are presented separately in this document.

\subsection{CAVEAT/LIMITATION OF SURROGATE APPLICATION}

The selection of surrogate materials is not (and will not be) an exact science; rather, there will be inherent uncertainties. First, a chemical and its surrogate may not always exhibit similar physical and chemical characteristics when operation conditions change over a wide range..$^{5,15}$ Second, waste streams may be inadequately characterized to formulate a completely faithful stimulant; sometimes a stimulant can be oversimplified, omitting relatively minor constituents that can affect the performance of the final treated waste form. For example, trace organic constituents, especially chelates, can unexpectedly alter the set conditions in cement-based solidification, ${ }^{16}$ and certain anions at moderate concentrations can interfere with cement solidification or the formation of a durable vitreous waste form.

The use of the authentic mixed waste streams in the development of treatment technologies adds considerable difficulties and complexity to the design and overall operation of an experimental facility. To handle the waste containing radioisotopes, the facility operator must obtain a NRC license and is legally obligated to the major task of decontamination and 
decommissioning of the facility after its being shut down. Treatability studies with RCRA materials have limitations on the amount of materiais that can be stored at a single site and the amount of material that can be tested in a single day. These limitations can greatly affect the ability to perform Research Development Demonstration Testing and Evaluation (RDDT\&E) on thermal treatment technologies.

In addition to permitting issues for the handling of radioactive and hazardous materials, issues such as health, safety, and environment have to be addressed and adhered to in accordance with DOE orders and various regulatory [i.e., EPA, NRC, Occupational Safety and Health Administration (OSHA), National Institute for Occupational Safety and Health (NIOSH)] requirements, all of which can result in substantial increases of both capital and operational costs, not to mention the potential adverse impact on the project schedule. Therefore, it is apparent that there is strong incentive to use surrogate formulations for the mixed waste streams. The use of surrogate materials for the hazardous and radioactive constituents will allow the expected behavior of the radiological and hazardous constituents to be evaluated while having less hazardous parameters than the actual waste streams.

The selection of surrogate materials is not an exact science and the selection process has inherent uncertainties. First, individual compounds and their respective surrogates may not exhibit the same physical and chemical characteristics when treatment conditions (e.g., temperature, halogen concentration, phase formation) change. Second, waste streams are for the most part inadequately characterized and the formulation of a rigorous surrogate (or stimulant) for an entire waste stream will be based upon many assumptions. Thus, trying to model a complex, heterogeneous system, which has been loosely defined, can only provide a rough level of resemblance to the original definition and may not closely model any specific waste stream. It is not surprising that there is no shortage of researchers who express the limitations and cautions regarding surrogate usage for hazardous waste stream selection and treatment.

Depending on the maturity of a process or technology, a tired approach to RDDT\&E can be adopted. During the initial evaluation of a new technology, a scoping study for example, surrogate materials would substitute radionuclides and hazardous chemicals in conducting the experiments, followed by phasing out of surrogates and into the total use of authentic ingredients after the experimental work brings more understandings and confidence for the process. The ability to define the composition of a waste stream also allows multiple facilities to test the "same" waste stream without complex shipping and handling procedures. Therefore, at the pilot-scale level, a process under development will be able to be compared as to their performance on treatment of "the same" or at least similar waste feed by the use of surrogate waste stream formulations with common hazardous surrogate or spike constituents (i.e., radiological, organic, and metal constituents). These same comparisons, as well as performance on "actual waste," can be made as processes are evaluated at site demonstrations. This will greatly assist in the comparison of various technologies to assess their efficacy in the treatment of a general type of waste stream. 


\section{WASTE SURROGATE RECIPES FOR THE PHP}

Surrogate recipes are formulated to simulate the compositions of real waste streams, if adequate characterization data are available, or to be as near representative of a generic waste stream category as the available information and data can provide guidance. In cases where no well-characterized representative authentic waste stream could be identified, a projected "representative" recipe is "assembled" by selecting the chemicals likely to be prevalent among the similar waste streams. Often, historical simulated waste compositions have to be referenced for such purpose as detailed characterizations for real wastes across DOE sites are presently very limited. These synthetic wastes were used in the past to simulate the essential properties of real wastes at various sites for experimental purposes, when obtaining or handling real waste was difficult and the proper use of surrogates could be justified. The information for real and simulated waste data used for surrogate formulation are generally extracted from DOE publications, conference papers, and inter-site memos, the references of which are cited wherever applicable.

Three waste categories were selected for the forthcoming PHP experiments by the Mixed Waste Integrated Program (MWIP), Mixed Waste Treatment Project (MWTP), and SAIC - they are inorganic sludge (3100), high organic content sludge (3122), and heterogeneous debris (5400). The numbers in the parentheses are waste stream category numbers which are employed to designate the respective waste streams in a classification system ${ }^{17}$ recently devised for DOE mixed waste streams by the MWTP team. The stimulant formulations for these three waste streams are presented separately in this report.

Initial testing at the Ukiah facility will utilize feed contained in standard 30-gal steel drums; formulations presented herein do not account for the contribution of the container to the total waste package. It is anticipated that one test run with each of the surrogate series will require two 30-gal. drums of material. Each drum contains $-350-500 \mathrm{lb}$ of material. Multiple runs may be required to ensure stack emission data quality.

Suggestions are given for mixing the constituents to achieve a degree of uniformity in the waste stream formulation. Additional mixing baffles or components can be added to the drum to ensure adequate mixing, but it is unclear whether this level of mixing is needed. It is noted that the physical strength of the drums for the surrogates should be consistent with the weight loading of the surrogate materials.

The basic surrogate formulation is broken into four parts: bulk ingredients, RCRA metals, RCRA organics, and radiological surrogates. The mixing procedure for each of the formulations is essentially the same to help ensure a consistent waste stream formulation can be made. The dry ingredients are placed into the drum and mixed. In a separate container the liquid RCRA organics (i.e., 1,2-dichlorobenzene, chlorobenzene) are combined with activated carbon and are then added to the drum. The water portion of the formulation is added last and the drum mixed and sealed. Step-by-step detail is given with each surrogate formulation.

The three RCRA organic components are, in general, the same for all surrogate formulations. The use of activated carbon is used in the surrogate formulation in order to do the following: (1) reduce the loss of the organic contaminant due to volatility, (2) reduce worker exposure risks, (3) increase the overall bulk volume of the hazardous organic component, and (4) assist in the mixing and uniform distribution of the hazardous organic component in the surrogate formulation. 
Naphthalene is a solid at room temperature and is mixed in with the other dry solid components of the formulation. The 1,2-dichlorobenzene and chlorobenzene are liquids, and in order to maximize the volume of the liquid fraction of the hazardous organic component, the two ingredients are added to the activated carbon. This will absorb the liquid phase present and allow the resultant solid phase mixture to be dispersed with the other dry solids and help reduce the loss of fugitive emissions. This provides a consistent means of hazardous organic addition that can be easily repeated for any of the surrogate formulations.

\subsection{INORGANIC MATRIX SOLIDS (MWTP-3100)}

\subsubsection{Waste Stream Definition}

Inorganic Matrix Solids, Waste Code 3100, are materials that have a high inorganic content, and as such they would yield a high ash residue by conventional incineration treatment. Subcategories in this waste code series include particulate inorganic media (e.g., ash, grit, vermiculite; Codes 3110-3112), sorbents such as clay, diatomaceous earth, perlite, and so forth (3113/4); zeolites (3115), sludges and filter cakes (3120) and so forth. These wastes may contain sorbed or interstitial hazardous organics and metals. The major treatment concerns are destruction of the organic impurities and immobilization of toxic metals into a glass or slag matrix.

The bulk components given in Sect. 3.1.2 are inferred from a companion report on waste water treatment sludges, ${ }^{18}$ data presented in Table 4 and references cited therein. ${ }^{8,19,20}$ Table 5 lists the recipe compositions.

Both diatomaceous earth and perlite have long been employed as filter aids in the filtration processes of many DOE-wide liquid waste treatment facilities; both materials are predominantly high surface area silica, but the perlite (a processed volcanic glass) has a higher concentration of trace impurities such as $\mathrm{Al}$ and $\mathrm{K}$. Dicalite Perlite (from, e.g., Grefco, Inc., or the equivalent) is recommended for the formulation because it is of lower cost than diatomaceous earth, and it has replaced the usage of the latter at some DOE facilities [e.g., Los Alamos National Laboratory (LANL)]. Perlite has large surface area per unit mass, and exhibits outstanding permeability as well as oil and water absorption characteristics. Other silica-based materials such as cured portland cement $\left(\mathrm{SiO}_{2}>20 \%\right)$, vermiculite (e.g., $\left.\mathrm{SiO}_{2}, 39 \%\right)$ are potential surrogate substitutes; each of these has somewhat different elemental composition, which may affect slag-forming properties. 
Table 4. Simulated inorganic sludge

[waste code 3100]

Nominal major component composition (weight \%, dry basis)

\begin{tabular}{|c|c|c|c|c|c|c|c|c|c|c|}
\hline \multirow[b]{2}{*}{ Reference } & \multicolumn{10}{|c|}{ Nominal major component composition (weight $\%$, dry basis) } \\
\hline & $\mathbf{A l}$ & $\mathrm{Fe}$ & $\mathrm{Si}$ & $\mathbf{C a}$ & $\mathbf{M g}$ & $\mathrm{Na}$ & $\mathbf{K}$ & Nitrate & Sulfate & Comments \\
\hline $\begin{array}{l}\text { This work } \\
\text { (Sect. 3.1.2) }\end{array}$ & 5.9 & 15.5 & 9.4 & 4.0 & 3.3 & 3.0 & - & 6.1 & 9.3 & Simulated 3100 Series Waste \\
\hline Bates (1993) & 8.7 & 11.4 & 3.8 & $<1$ & 8.8 & - & 16.6 & - & - & $\begin{array}{l}\text { Simulated, cement-solidified RFP } \\
74 \text { series sludge stored at INEL } \\
\text { (Pit 9); proposed as buried waste } \\
\text { program standard }\end{array}$ \\
\hline Sprenger et al. (1993) & - & 16.2 & 3.9 & 9.1 & 5.3 & 2.6 & - & 6.9 & 21.5 & Simulated RFP sludge \\
\hline Bostick et al. (1993) & 7.9 & 22.2 & 6.6 & 10.3 & 1.2 & 2.3 & 3.6 & - & 0.1 & Simulated K-25 Site Pond Waste \\
\hline Kupfer et al. (1981) & 10.1 & 34 & 4.4 & 2.5 & - & 9.1 & - & - & 0.5 & $\begin{array}{l}\text { Simulated calcinated Hanford } \\
\text { Purex Sludge }\end{array}$ \\
\hline
\end{tabular}

Sources: S. O. Bates, Report EGG-WTD-1066 (1993), G. S. Sprenger et al., in Proceedings 1993 Incineration Conference, Knox ville, Tenn., p. 291, W. D. Bostick et al., Report DOE/MWIP-18 (1993), and M. J. Kupfer et al., DOE/ET/41900-8 (EGG-DOE-13352) (1981). 


\subsubsection{Surrogate Formulation}

Table 5. MWTP 3100: Inorganic matrix solids

\begin{tabular}{|c|c|c|}
\hline No. & Component Name & Wt \% \\
\hline \multicolumn{3}{|c|}{ Bulk ingredient } \\
\hline 1 & Activated carbon & 5 \\
\hline 2 & Water & 15 \\
\hline 3 & Perlite $\left(\mathrm{SiO}_{2}\right)$ & 18 \\
\hline 4 & $\mathrm{Fe}_{2} \mathrm{O}_{3}$ & 20 \\
\hline 5 & $\mathrm{CaSO}_{4} * 2 \mathrm{H}_{2} \mathrm{O}$ & 15 \\
\hline 6 & $\mathrm{Al}_{2} \mathrm{O}_{3}$ & 10 \\
\hline 7 & $\mathrm{NaNO}_{3}$ & 10 \\
\hline \multirow[t]{2}{*}{8} & $\mathrm{MgO}$ & 4.5 \\
\hline & Total & 97.5 \\
\hline \multicolumn{3}{|c|}{ RCRA Metals } \\
\hline 9 & $\mathrm{Cr}_{2} \mathrm{O}_{3}$ & 0.25 \\
\hline 10 & $\mathrm{NiO}$ & 0.25 \\
\hline 11 & $\mathrm{PbO}$ & 0.25 \\
\hline \multirow[t]{2}{*}{12} & $\mathrm{CdO}$ & 0.25 \\
\hline & Total & 1.0 \\
\hline \multicolumn{3}{|c|}{ RCRA Organics } \\
\hline 13 & Naphthalene $\left(\mathrm{C}_{10} \mathrm{H}_{8}\right)$ & 0.4 \\
\hline 14 & 1,2-Dichlorobenzene $\left(\mathrm{C}_{6} \mathrm{H}_{4} \mathrm{Cl}_{2}\right)$ & 0.3 \\
\hline \multirow[t]{2}{*}{15} & Chlorobenzene $\left(\mathrm{C}_{6} \mathrm{H}_{5} \mathrm{Cl}\right)$ & 0.3 \\
\hline & Total & 1.0 \\
\hline \multicolumn{3}{|c|}{ Radionuclide Surrogate } \\
\hline 16 & $\mathrm{CeO}_{2}$ & 0.25 \\
\hline \multirow[t]{2}{*}{17} & $\mathrm{CsCl}$ & 0.25 \\
\hline & Total & 0.5 \\
\hline
\end{tabular}




\subsubsection{Mixing Suggestion}

Table 6. MWTP 3100: Inorganic matrix solids

\begin{tabular}{cl}
\hline Step no. & \multicolumn{1}{c}{ Sequence/instructions } \\
\hline 1 & Weigh drum and lid and record. \\
2 & $\begin{array}{l}\text { To the drum add (in an alternating manner as to ensure better mixing) all of } \\
\text { the following dry constituents: } 3-13,16,17\end{array}$ \\
3 & Stir/roll drum for $\geq 5$ minutes. \\
4 & Weigh drum, lid, and mixture and record. \\
5 & $\begin{array}{l}\text { Add the activated carbon (1) to a separate mixing container. Slowiy add the } \\
\text { liquid } \text { RCRA organics (14,15) and mix the two components until the liquids } \\
\text { are absorbed. }\end{array}$ \\
6 & Add the activated carbon/RCRA organic mixture (step 5) into the drum. \\
7 & Stir/roll drum for $\geq 5$ minutes. \\
8 & Slowly add the water (2) to the mixed solids in the drum. \\
9 & Stir/roll the drum for $\geq 15$ minutes. Seal the drum. \\
10 & Weigh drum, lid and surrogate waste stream mixture and record.
\end{tabular}

\subsection{HIGH ORGANIC CONTENT SLUDGES (MWTP-3122)}

\subsubsection{Waste Stream Definition}

This waste stream includes sludges with $>1 \%$ hazardous organic (halogenated or nonhalogenated) material. ${ }^{17}$ The EPA hazardous waste codes of concern for treatment are F001-4 (solvent residuals), and toxic metal constituents [D004-D011]. ${ }^{17}$

An example of a waste water sludge containing relatively high organic residue is the Central Pollution Control Facility (CPCF) sludge, originating from treatment of waste from the Oak Ridge Y-12 Plant; this material contained $-23 w t \%$ ill-defined "oil and grease" component in an inorganic oxyhydroxide sludge matrix (high $\mathrm{Ca}, \mathrm{Fe}, \mathrm{Al}$, with moderate amounts of $\mathrm{P}$ ). ${ }^{21}$ The hazardous organics in the CPCF sludge included various phenolic compounds. The CPCF sludge, and the general compositions of various waste water treatment sludges, ${ }^{18}$ serve to model the bulk constituents in the surrogate presented in Sect. 3.2.2 (Table 7). The mixing suggestion is given in Table 8. 
3.2.2 Surrogate Formulation

Table 7. MWTP 3122: High organic content sludges

\begin{tabular}{|c|c|c|}
\hline No. & Component Name & $\mathrm{Wt} \%$ \\
\hline \multicolumn{3}{|c|}{ Bulk Ingredient } \\
\hline 1 & Activated carbon & 10 \\
\hline 2 & Water & 20 \\
\hline 3 & Perlite & 10 \\
\hline 4 & $\mathrm{Fe}_{2} \mathrm{O}_{3}$ & 10 \\
\hline 5 & $\mathrm{CaSO}_{4} * 2 \mathrm{H}_{2} \mathrm{O}$ & 10 \\
\hline 6 & $\mathrm{Al}_{2} \mathrm{O}_{3}$ & 5 \\
\hline 7 & Ethylene glycol & 14.5 \\
\hline \multirow[t]{2}{*}{8} & Mineral oil & 12.0 \\
\hline & Total & 91.5 \\
\hline \multicolumn{3}{|c|}{ RCRA Metals } \\
\hline 9 & $\mathrm{CrCl}_{3} * 6 \mathrm{H}_{2} \mathrm{O}$ & 0.25 \\
\hline 10 & $\mathrm{NiCl}_{2} * 6 \mathrm{H}_{2} \mathrm{O}$ & 0.25 \\
\hline 11 & $\mathrm{PbCl}_{2}$ & 0.25 \\
\hline \multirow[t]{2}{*}{12} & $\mathrm{CdCl}_{2} * 21 / 2 \mathrm{H}_{2} \mathrm{O}$ & 0.25 \\
\hline & Total & 1.0 \\
\hline \multicolumn{3}{|c|}{ RCRA Organics } \\
\hline 13 & Naphthalene $\left(\mathrm{C}_{10} \mathrm{H}_{8}\right)$ & 3 \\
\hline 14 & 1,2-Dichlorobenzene $\left(\mathrm{C}_{6} \mathrm{H}_{4} \mathrm{Cl}_{2}\right)$ & 2 \\
\hline \multirow[t]{2}{*}{15} & Chlorobenzene $\left(\mathrm{C}_{6} \mathrm{H}_{5} \mathrm{Cl}\right)$ & 2 \\
\hline & Total & 7 \\
\hline \multicolumn{3}{|c|}{ Radionuclide Surrogate } \\
\hline 16 & $\mathrm{CeCl}_{3}$ & 0.25 \\
\hline \multirow[t]{2}{*}{17} & $\mathrm{CsCl}$ & 0.25 \\
\hline & Total & 0.5 \\
\hline
\end{tabular}




\subsubsection{Mixing Suggestion}

Table 8. MWTP 3122: High organic content sludges

\begin{tabular}{cl}
\hline Step no. & \multicolumn{1}{c}{ Sequence/instructions } \\
\hline 1 & Weigh drum and lid and record. \\
2 & $\begin{array}{l}\text { To the drum add (in an alternating manner as to ensure better mixing) all of } \\
\text { the following dry constituents: } 3-13,16,17 .\end{array}$ \\
3 & Stir/roll drum for $\geq 5$ minutes. \\
4 & Weigh drum, lid, and mixture and record. \\
5 & $\begin{array}{l}\text { Add the activated carbon }(:) \text { to a separate mixing container. Slowly add the } \\
\text { liquid RCRA organics }(14,15) \text { and mix the two components until the liquids }\end{array}$ \\
6 & are absorbed. \\
7 & Add the activated carbon/RCRA organic mixture (step 5) into the drum. \\
8 & Stir/roll drum for $\geq 5$ minutes. \\
9 & Stir/roll the drum for $\geq 15$ minutes. Seal the drum. \\
10 & Weigh drum, lid and surrogate waste stream mixture and record.
\end{tabular}

\subsection{HETEROGENEOUS DEBRIS (MWTP-5400)}

\subsubsection{Waste Stream Definition}

The waste stream comprises debris materials that contain $-50 \%$ combustible materials intermingled with noncombustible debris and the mix stabilizers (activated carbon and cation exchange resin) As heterogeneous debris, these materials may be associated with a variety of EPA waste codes (e.g., F001-05, D004-11). ${ }^{17}$

Previous waste stream characterization ${ }^{22,23}$ was used in part in establishing the major combustible constituents and associated concentrations where as values reported in references ${ }^{24.25}$ were used to establish the major noncombustible constituents and their associated concentrations.

The specifications of the combustible species/fractions were done in conjunction with reviewing the MWTP waste code 5440, which was patterned after buried wastes originally generated at the RFP and currently buried at INEL. The specifications of the non-combustible species were done in conjunction with reviewing the appropriate proposed rules published in 1992 in the Federal Register. ${ }^{26}$ The May 26, 1992 Federal Register ${ }^{26}$ defines treatability group \#13 as relevant for solid debris wastes that exhibit the characteristics of toxicity due to metals (D004-D011) with matrices that are nonfriable, inorganic solids, glass, concrete, refractory bricks, slags, and metal industrial equipment are included therein. 
Table 9, which lists some attributes of bulk combustibles and simulated heterogeneous debris that have been used previously in testing incinerator performance, was also used. Polyvinyl chloride (PVC) and neoprene were added, in addition to the trace components, to ensure sufficient chlorine potential was present in the combustion chamber to ascertain some sensitivity data of the volatile species and transport reactions with the trace RCRA and radiological surrogate metals. Based upon the bulk combustible surrogate formulation in Table 10, there will be $-9.9 \mathrm{lb}$ of $\mathrm{Cl}$ per $100 \mathrm{lbs}$ of waste. Thus, the total feed rate will have to be controlled to ensure compliance with test site chlorine emission limits. 
Table 9. Simulated heterogeneous, predominantly combustible waste compositions [waste codes 5300 (combustible debris)/5400 (heterogeneous debris)]

\begin{tabular}{|c|c|c|c|c|}
\hline \multirow[b]{2}{*}{ Reference } & \multicolumn{3}{|c|}{ Stimulant composition (wt \%) } & \multirow[b]{2}{*}{ Comments } \\
\hline & Plastics/polymers & Cellulosics & Noncombustible & \\
\hline $\begin{array}{l}\text { Pattengill } \\
\text { et al. (1982) }\end{array}$ & $\begin{array}{l}\text { Polyethylene (9\%) } \\
\text { PVC } \quad(6 \%)\end{array}$ & Cloth (7\%) & Shredded steel (33\%) & $\begin{array}{l}\text { Incineration of simulated TRU wastes } \\
\text { from INEL: Combustible filled drum. } \\
\text { Data on ash composition, particle size. } \\
\text { distribution, etc. }\end{array}$ \\
\hline $\begin{array}{l}\text { Tenaglia and } \\
\text { McCall } \\
\text { (1983) }\end{array}$ & $\begin{array}{l}\text { Polyethylene }(73 \%) \\
\text { PVC } \quad(8 \%)\end{array}$ & $\begin{array}{l}\text { Wood }(5 \%) \\
\text { Paper }(5 \%) \\
\text { Cloth }(9 \%)\end{array}$ & $\begin{array}{l}\text { [Various noncombustibles, e.g. } \\
\text { soil, glass, firebrick, cryolite, } \\
\text { sludge, and cement were blended } \\
\text { with combustible mix.] }\end{array}$ & $\begin{array}{l}\text { Induction melting of simulated TRU } \\
\text { waste; characterization data for all } \\
\text { products and residuals }\end{array}$ \\
\hline $\begin{array}{l}\text { Ford and Jenkins } \\
\text { (1984) }\end{array}$ & $\begin{array}{l}\text { PVC } \quad(49.4 \%) \\
\text { Polyethylene }(10.4 \%) \\
\text { Polypropylene }(11.7 \%) \\
\text { Hypalon } \quad(19.9 \%)\end{array}$ & Tissues $(8.6 \%)$ & N/A & $\begin{array}{l}\text { Incineration of simulated TRU waste from } \\
\text { BNFL }\end{array}$ \\
\hline $\begin{array}{l}\text { Ford and Jenkins } \\
\text { (1984) }\end{array}$ & $\begin{array}{ll}\text { PVC } & (8.8 \%) \\
\text { Polyethylene } & (30 \%) \\
\text { Neoprene } & (20.3 \%) \\
\text { Hypalon } & (5.4 \%) \\
\text { Polyurethane } & (8.8 \%)\end{array}$ & Tissues (15\%) & N/A & $\begin{array}{l}\text { Incineration of simulated TRU waste from } \\
\text { DNE }\end{array}$ \\
\hline $\begin{array}{l}\text { Brunel et al. } \\
\text { (1992) }\end{array}$ & $\begin{array}{lc}\text { PVC } & (50 \%) \\
\text { Neoprene } & (27 \%) \\
\text { Latex } & (15 \%)\end{array}$ & $\begin{array}{l}\text { Cotton }(4 \%) \\
\text { Tissues }(4 \%)\end{array}$ & N/A & $\begin{array}{l}\text { Incineration of simulated waste from } \\
\text { French mixed oxide fuel facility; } \\
\text { characterized ash. tested ash stabilization }\end{array}$ \\
\hline $\begin{array}{l}\text { Gilmore (ed) } \\
(1977)\end{array}$ & $\begin{array}{ll}\text { Rubber tubing }(15 \%) \\
\text { Neoprene } \quad(15 \%) \\
\text { PVC } & (20 \%) \\
\text { Tygon } & (10 \%) \\
\text { Polyethylene } & (10 \%)\end{array}$ & $\begin{array}{l}\text { Tissues }(15 \%) \\
\text { Rags (15\%) }\end{array}$ & N/A & $\begin{array}{l}\text { Pyrolysis/incineration of simulated alpha- } \\
\text { waste at Battelle Northwest Laboratories: } \\
\text { ash products characterized }\end{array}$ \\
\hline
\end{tabular}

Sources: M. G. Pattengill et al., Report EGG-2223 (1982), R. D. Tenaglia and J. L. McCall, Report EGG-2263 (1983), L. H. Ford and M. J. Jenkins, Report EUR-9219-EN (1984), G. R. Brunel, C. J. Kertesz, and L. M. Auffret, in Waste Management '92 (1992), p. 1459, and W. R. Gilmore (ed), Radioactive Waste Disposal (Low and High Level), Noyes Data Corporation (1977), p. 153. 


\subsubsection{Surrogate Formulation}

Table 10. MWTP 5400: Heterogeneous debris

\begin{tabular}{|c|c|c|}
\hline No. & Component Name & $\mathrm{Wt} \%$ \\
\hline \multicolumn{3}{|c|}{ Bulk ingredient } \\
\hline 1 & Activated carbon & 5 \\
\hline 2 & Water & 14.5 \\
\hline 3 & Wood & 10 \\
\hline 4 & Polyvinylchloride (PVC) & 10 \\
\hline 5 & Neoprene & 10 \\
\hline 6 & Mild steel & 10 \\
\hline 7 & Glass beads & 10 \\
\hline 8 & Concrete (cured, crushed) & 8 \\
\hline 9 & Alumina crucibles & 10 \\
\hline \multirow[t]{2}{*}{10} & Diatomaceous earth & 10 \\
\hline & Total & 97.5 \\
\hline \multicolumn{3}{|c|}{ RCRA metals } \\
\hline 11 & $\mathrm{CrCl}_{3} * 6 \mathrm{H}_{2} \mathrm{O}$ & 0.25 \\
\hline 12 & $\mathrm{NiCl}_{2} * 6 \mathrm{H}_{2} \mathrm{O}$ & 0.25 \\
\hline 13 & $\mathrm{PbCl}_{2}$ & 0.25 \\
\hline \multirow[t]{2}{*}{14} & $\mathrm{CdCl}_{2} * 21 / 2 \mathrm{H}_{2} \mathrm{O}$ & 0.25 \\
\hline & Total & 1.0 \\
\hline \multicolumn{3}{|c|}{ RCRA organics } \\
\hline 15 & Naphthalene $\left(\mathrm{C}_{10} \mathrm{H}_{8}\right)$ & 0.4 \\
\hline 16 & 1,2-Dichlorobenzene $\left(\mathrm{C}_{6} \mathrm{H}_{4} \mathrm{Cl}_{2}\right)$ & 0.3 \\
\hline \multirow[t]{2}{*}{17} & Chlorobenzene $\left(\mathrm{C}_{6} \mathrm{H}_{5} \mathrm{Cl}\right)$ & 0.3 \\
\hline & Total & 1.0 \\
\hline \multicolumn{3}{|c|}{ Radionuclide surrogate } \\
\hline 18 & $\mathrm{CeCl}_{3}$ & 0.25 \\
\hline \multirow[t]{2}{*}{19} & $\mathrm{CsCl}$ & 0.25 \\
\hline & Total & 0.5 \\
\hline
\end{tabular}




\subsubsection{Mixing Suggestion}

Table 11. MWTP 5400: Heterogeneous debris

\begin{tabular}{cl}
\hline Step no. & \multicolumn{1}{c}{ Sequence/instructions } \\
\hline 1 & Weigh drum and lid and record. \\
2 & $\begin{array}{l}\text { To the drum add (in an alternating manner as to ensure better mixing) all of } \\
\text { the following dry constituents: } 3-15,18,19 .\end{array}$ \\
3 & Stir/roll drum for $\geq 5$ minutes. \\
4 & Weigh drum, lid, and mixture and record. \\
5 & $\begin{array}{l}\text { Acid the activated carbon (1) to a separate mixing container. Slowly add the } \\
\text { liquid RCRA organics (16,17) und mix the two components until the liquids }\end{array}$ \\
6 & are absorbed. \\
7 & Add the activated carbon/RCRA organic mixture (step 5) into the drum. \\
8 & Stowly add the water (2) to the mixed solids in the drum. \\
9 & Stir/roll the drum for $\geq 15$ minutes. Seal the drum. \\
10 & Weigh drum, lid and surrogate waste stream mixture and record.
\end{tabular}




\section{SUMMARY}

The simulated waste packages presented in the text do not necessarily represent an individual waste stream within the DOE complex; rather, they were formulated to represent the most probable components in generic waste stream categories. Suggestions are given for mixing the constituents to achieve a degree of homogeneity; however, mixing of the ingredients on a scale required for preparation of 30 -gal waste packages has not been demonstrated at this date. Additional mixing baffles or components can be added to the drum to ensure adequate mixing, but it is unclear whether this level of mixing is needed.

The presence of nitrate salts and organic constituents in the same waste packages, although representative of some mixed wastes, is not inherently thermodynamically stable, and energetic oxidative reactions may occur during high-temperature melting of the packages. However, significant quantities of nitrates are only present in the inorganic matrix waste (Waste code 3100), and should pose no inordinate risk. If long storage time of the wastes is anticipated, the drums can be fitted with a pressure relief cap to ensure that no organics can readily escape and that overpressurization of the drum does not occur.

It is also noted that a source of chlorine in each surrogate formulation is the 1,2 dichlorobenzene, which is present at such low quantities that the risk associated with the emission is negligible. For the heterogeneous debris waste formulation (5400) PVC and neoprene, in addition to the RCRA organics, are added to ensure sufficient chlorine potential was present in the combustion chamber to ascertain some sensitivity data for the volatile species and transport reactions with the trace RCRA and radiological surrogate metals. Based upon the bulk combustible surrogate formulation in Table 10 there will be $-9.9 \mathrm{lbs}$ of $\mathrm{Cl}$ per $100 \mathrm{lbs}$. of surrogate waste stream. Thus, the total number of drums and their feed rate will have to be controlled to ensure compliance with test site chlorine emission limits.

A companion report ${ }^{27}$ describes surrogates for a number of other select waste stream categories that should be amenable to treatment by a robust melter technology such as the PHP. These technologies are expected to have inherent advantages in processing inorganic residuals. The companion report ${ }^{27}$ presents surrogate formulations for some of these candidate waste streams including, Ash (3110); Cement sludges, Ashes, and Solids (3140); Heterogeneous Debris (5400); Lab Packs (6100); and Lead Shapes (7200).

In addition, reports on the benchmarking of thermal treatment technologies ${ }^{28}$ and the data quality objectives for thermal treatment of mixed waste will be forthcoming. Utilizing consistent methods of process documentation and process control in conjunction with consistent waste stream compositions (i.e., surrogates) will allow an enhanced comparison of various thermal treatment technologies.

NOTE ADDED IN PRESS: Performance assessment of the plasma hearth process for treatment of surrogate wastes (based upon earlier DRAFT surrogate formulations) is reported by R. Geimer et al., in "Plasma Hearth Process Test Results Under the DOE Mixed Waste Integrated Program," Proceedings of 13th International Incineration Conference, Houston, Texas, May 9-14, 1994. 


\section{REFERENCES}

1. U.S. DOE Interim Mixed Waste Inventory Report, DOE/NBM-1100, Vol. 1-Overview, April 1993.

2. T. D. Kirkpatrick, EG\&G Idaho, et al., "DOE Mixed LOW-Level Waste Overview."

3. U.S. Environmental Protection Agency. Land disposal restrictions for newly listed wastes and contaminated debris:proposed rule. 40 CFR Parts 148, 260, 261, 268, et al.

4. J. A. D. Stockdale, W. D. Bostick, D. P. Hoffmann, and Hom-Ti Lee, "Surrogate Formulations for Thermal Treatment of Low-Level Mixed Waste, Part I: Radiological Surrogates," Report DOE/MWIP-15, January 1994.

5. W. J. Bjorklund, "Development and Use of Sintered High Level Waste," Report BNNW-2074, Battelle Pacific Northwest Laboratories, Richland, Wash. (July 1976).

6. C. Shapiro, K. Garcia, and J. Beller, "Treatment of a Simulated Mixed Waste with Supercritical Water Oxidation," in A. Moghissi et al. (eds), Proceedings of the Second International Symposium on Mixed Waste, Baltimore, Md., August 17-20, 1993, pp. 10.3.1-10.3.16.

7. S. O. Bates, "Definition and Compositions of Standard Waste Streams for Evaluation of Buried Waste Integrated Demonstration Treatment Technologies," Report EGG-WTD-1066 (January 1993).

8. C. C. Lee, G. L. Huffman, and S. M. Sasseville, "Incinerability Ranking Systems for RCRA Hazardous Constituents," Hazardous Waste and Hazardous Materials, 7(4), 1990.

9. R. D. Spence, T. M. Gilliam, I. L. Morgan, and S. C. Osborne, "Immobilization of Volatile Organic Compounds in Commercial Cement-Based Waste Forms," Report ORNL/TM11251, Martin Marietta Energy Systems, Inc., December 1990.

10. M. T. Harris, R. L. Jolley, G. E. Oswald, and J. C. Rose, "Wet Oxidation of Phenol and Naphthalene (as a Surrogate PAH) in Aqueous and Sludge Solution: Application to Coal Conversion Wastewater and Sludge Treatment," Report ORNL/TM-8576, Union Carbide Corp., May 1983.

11. R. W. Anderson, "Recommended Surrogate PCB Waste Feed and Fuel Compositions to Meet Spec. KND-5552 for Test Burns in the Martin Marietta Energy Systems, Inc., Incinerator," Report KJPS-975, December 1984.

12. P. Sadler, "Understanding Metals Compliance: The Tired Approach and Dealing With Multiple Sources," in Proceedings of the 1993 Incineration Conference, Knoxville, Tenn., May 3-7, 1993, p. 405.

13. J. M. Hillary, "Review of the 'Trial Bum Manual for the Testing of Metals': A Product of the Coalition for Responsible Waste Incineration," in Proceedings of the 1993 Incineration Conference, Knoxville, Tenn., May 3-7, 1993, p. 411.

14. J. R. Waterland and D. J. Fournier, "Potential Surrogate Metals for Incinerator Trial Burns," in Proceedings of the 1993 Incineration Conference, Knoxville, Tenn., May 3-7, 1993, p. 433.

15. C. R. Dempsey and E. Timothy, "Incineration of Hazardous Waste: A Critical Review Update," Air \& Waste, Vol. 43, January 1993.

16. T. F. Lomenick, "Proceedings of the Workshop on Radioactive , Hazardous, and/or Mixed Waste Sludge Mlanagement," Report CONF-901264, Martin Marietta Energy Systems, Inc.

17. John Mayberry, SAIC, memorandum to MWTP Team Members, February 5, 1993. 
18. W. D. Bostick, D. F. Bickford, et al. "Surrogate Formulations for Thermal Treatment of Low-Level Mixed Wastes. Part IV: Waste Water Treatment Sludges," DOE/MWIP-18, January 1994.

19. G. S. Sprenger, "Critical Operating Parameters For Microwave Solidification of Hydroxide Sludge" Mixed Waste Symposium Proceedings, August 1993.

20. M. J. Kupfer, "Preparation of Nonradioactive Substitutes for Radioactive Wastes," DOE/ET/41900-8 (EGG-DOE-13352), Rockwell Hanford Operations (July 1981).

21. R. L. Fellows, W. D. Bostick, J. L. Shoemaker, and I. L. Morgan, "Extraction of Organics from Sludge: CPCF Sludge Extraction Evaluation - Bench-Scale Chemistry Tests," Report K/QT-406, Martin Marietta Energy Systems, Inc., April 1991.

22. W. R. Gilmore (ed.), "Radioactive Waste Disposal (Low and High Level)," Noyes Data Corporation (1977).

23. L. H. Ford and M. J. Jenkins, "Commission of the European Communities, Nuclear Science and Technology, Incineration of Simulated Plutonium-Contaminated Waste," EUR 9219 EN, Directorate-General, Science, Research and Development, United Kingdom Atomic Energy Authority, Springfields Nuclear Power Development Laboratories, Salwick, Preston PR4 ORR, United Kingdom, 1984, Final Report.

24. T. L. Eddy, P. C. Kong, B. D. Ralvo, and G. L. Anderson, "Thermal Processing System Concepts and Considerations for RWMC Buried Waste," EGG-WTD-10058, DE92 018049. Idaho National Engineering Laboratory, EG\&G Idaho, Inc., Idaho Falls, Idaho 83415, February 1992.

25. H. E. Martz, G. P. Roberson, D. J. Schneberk, M. F. Skeate, D. Perkins, and S. G. Azevedo, "Computerized Tomography of a Simulated Waste Canister," UCID-21940, DE90 008014, Nondestructive Evaluation Section, Lawrence Livermore National Laboratory, Livermore, Calif. 94551.

26. U.S. EPA, 57 FR 22027, May 26, 1992.

27. W. D. Bostick, et al. "Surrogate Formulations for Thermal Treatment of Low-Level Mixed Wastes. Part II: Selected Mixed Waste Treatment Project Waste Streams," DOE/MWIP-16, January 1994.

28. D. P. Hoffmann et al. "Guidelines for Benchmarking Thermal Treatment Systems for Low-Level Mixed Wastes," DOE/MWIP-19, January 1994.

29. D. P. Hoffmann, L. V. Gibson, Jr., W. H. Hermes, R. E. Bastian, A. R. Eicher, "Data Quality Objectives: Evaluation of Thermal Treatment Processes," DOE/MWIP-22, December 1993 (DRAFT). 


\section{APPENDIX}

Materials List and Suggested Vendors 


\section{INTERNAL DISTRIBUTION}

1. T. Abraham

2. W. Altman

3. W. Anderson

4. P. Fackus

5. M. Baer

6. M. Baker

7. H. Beeson

8-13. J. Berry

14. G. Bloom

15. V. Boris

16. W. Bostick

17. C. Brown

18. C. Buttram

19. R. Cannon

20. J. Chiang

21. A. Croff

22. T. Conley

23. S. Crosley

24. C. Daugherty

25. L. Dole

26. J. Dunn

27. M. Elmore

28. R. Fellows

29. C. Frye

30. R. Genung

31. L. Gibson

32. M. Gilliam

33. R. Glass

34. E. Harrington

35. H. Haselton
36. H. Hayden

37. W. Hermes

38. B. Hightower

39. D. Hoffman

40. D. Hutchins

41. G. Kamp

42. J. Kennerly

43. S. Kimmett

44. D. Kucsmas

45. H. Lee

46. D. Lennon

47. A. Malinauskas

48. A. Mattus

49. C. Mattus

50. E. McDaniel

51. D. Milewski

52. M. Morris

53. D. Moser

54. C. Newman

55. J. Perona

56. A. Richmond

57. T. Rogers

58. R. Sams

59. L. Stinton

60. P. Wayland

61. Central Research Library

62. Document Reference Center

63. ORNL Patent Section

64-65. ORNL Laboratory Records

66. ORNL Laboratory Records, RC 


\section{EXTERNAL DISTRIBUTION}

67. Dr. Martin G. Adamson, Lawrence Livermore National Laboratory, P. O. Box 808, L-591, Livermore, CA 94550

68. N. Askew, Westinghouse Savannah River Co., P. O. Box 616, Aiken, SC 29802

69. Dr. Chris Atkinson, West Virginia University, P. O. Box 6106, Morgantown, WV 26506

70. C. Baldwin, EG\&G Rocky Flats, P.O. Box 464, Highwa; \& \& Cactus, Bldg. 881, Golden, CO 80402-0464

71. M. Ballestri, BDM Federal, 20251 Century Blvd., 4th Floor, Germantown, MD 20874

72. Dr. John Barghusen, META, Inc., 814 W. Diamond Ave., Gaithersburg, MD 20878

73. L. M. Barton, Jr., Vortec Corporation, 3370 Ridge Pike, Collegeville, PA 19426-3158

74. J. Bassi, EM-351, U.S. Department of Energy, 12850 Middlebrook Road, Germantown, MD 20874

75. R. Bastian, Focus Environmental, 9050 Executive Park Drive, Suite A-202, Knoxville, TN 37923

76. S. Bates, EG\&G Idaho Inc., P.O. Box 1625, MS-3930, Idaho Falls, ID 83415-3930

77. T. Bergsman, Battelle Pacific Northwest Laboratory, Battelle Boulevard, MS P7-41, Richland, WA 99352

78. D. Bickford, Westinghouse Savannah River Co., P. O. Box 616, Bldg. 773-A, Aiken, South Carolina 29802

79. P. Biswas, Environmental Engineering, University of Cincinnati, Cincinnati, $\mathrm{OH}$ 45221-0071

80. W. J. Bjorklund, Waste Management Section, Laboratory Safety Department, Battelle Pacific Northwest Labs, P.O. Box 999, Richland, WA 99352

81. David Black, Argonne National Laboratory, 9700 S. Cass Ave., TD/207, Argonne, IL 60439

82. Jeffrey Bloom, Waste Policy Institute, 555 Quince Orchard Rd., Suite 600, Gaithersburg, MD 20878

83. L. Borduin, Los Alamos National Laboratory, One Bikini Road, MS K557, Los Alamos, NM 87545

84. Steve Bossart, U.S. Department of Energy, P. O. Box 880, MS-E06, Morgantown, WV 26507

85. M. Brooks, Waste Policy Institute, 555 Quince Orchard Blvd., Suite 600, Gaithersburg, MD 20879

86. D. Brooman, Belfort Engineering Services, 20201 Century Blvd., Bellemeade Bldg.

4th Floor, Germantown, MD 20874

87. G. Bryan, Pacific Northwest Lab, Battelle Blvd., Richland, WA 99352

88. Steve Buelow, Los Alamos National Lab, P. O. Box 616, MS J567, Los Alamos, NM 87545

89. H. Burns, Westinghouse Savannah River Co., P. O. Box 616, Bldg. 704-61S, Aiken, SC 29808

90. P. Castle, U.S. DOE/HQ, WINCO, 20201 Century Blvd., Rm. 408, Germantown, MD 20874

91. D. Chaiko, Argonne National Lab, 9700 S. Cass Ave., CMT/Bldg. 205, Argonne, IL 60439

92. W. Clark, Energy and Environmental Research Corporation, 18 Mason, Irvine, CA 92718

93. C. Collier, BDM Federal, 20251 Century Blvd., 4th Floor, Germantown, MD 20874

94. Dr. Robert Cook, Mississippi State University, P. O. Drawer MM, 320 Etheredge Engineering Bldg., Mississippi State, MS 39762-5932 
95. C. Cooley, EM-5t, U.S. Department of Energy, Trevion II, Washington, DC 20585-0002

96. T. Cooper, Westinghiouse Hanford Corp., 2355 Stevens Dr., MS N3-12, Richland, WA 99352

97. J. Cooper, Chester Environmental, 12242, S.W. Garden Place, Tigard OR 97223

98. A. Corstillo, FERMCO, 25 Merchant St., 3rd Floor Technology, Springdale, OH 45246

99. S. Couture, Lawrence Livermore National Lab, P.O. Box 808, L-591, Livermore, CA 94551

100. G. Coyle, EM-541, U.S. Department of Energy, 12800 Middlebrook Road, Trevion II, Germantown, MD 20874-1290

101. P. Coyle, EM-55, U.S. Department of Energy, 19901 Germantown Road, Germantown, MD 20874

102. J. Cudalty, Focus Environmental, 9050 Executive Park Drive, Suite A-202, Knoxville, TN 37923

103. J. Cunnane, Argonne National Lab, 9700 South Cass Ave., Bldg. 205, Argonne, IL 60439

104. J. Dancz, SAIC, Quince Diamond Executive Center, 555 Quince Orchard Rd., Suite 500, Gaithersburg, MD 20878-4137

105. W. Davis, University of Tennessee, College of Engineering, Knoxville, TN 37996-2010

106. C. Dempsey, Risk Reduction Lab, US EPA, Cincinnati, OH 45224

107. Patrick M. Dhooge, Delphi Research, Inc., 701 Haines Ave. NW, Albuquerque, NM 87102

108. L. Dole, Environmental Remediation Consultant, 2108 Granada Blvd., Knoxville, TN 37922

109. S. Domotor, EM-332, U.S. Department of Energy, Trevion II, Washington, D.C. 20585

110. Keith Duam, EG\&G Idaho, P. O. Box 1625, Idaho Falls, ID 83415-3910

111. M. Durham, ADA Technologies Inc., 304 Inverness Way South, Suite 110, Englewood, CO 80112

112. A. Eicher, Focus Environmental, 9050 Executive Park Drive, Suite A-202, Knoxville, TN 37923

113. P. Erickson, EPA-RREL, 5995 Center Hill Ave., Cincinnati, OH 45224

114. R. Eschenbach, Retech, Inc., P.O. Box 997, 100 Henry Station Road, Uriah, CA $95482-$ 0997

115. J. Fannon, EM-50, U.S. DOE, HQ, 20201 Century Blvd., Bellmeade Bldg. II, Rm. 402, Germantown, MD 20874

116. C. Frank, EM-50, U.S. Department of Energy, Forrestal Office Building, Washington, DC 20585

117. E. Franz, Brookhaven National Lab, Environmental \& Waste Technology Center, North Railroad St., Bldg. 830, Upton, NY 11973

118. G. Frazier, University of Tennessee, College of Engineering, Knoxville, TN 379962010

119. Dr. N. French, Sandia National Laboratory Livermore, 7011 East Avenue, Livermore, CA 94550

120. M. Fuhrmann, Brookhaven National Laboratory, Building 703, Upton, NY 11973

121. A. Gatuchette, US EPA, Risk Reduction Engineering Lab, 26 W. Martin Luther King Blvd., Cincinnati, OH 45268

122. R. Gay, Rockwell International, 6633 Canoga Ave., MS-T006, Canoga Park, CA 91309-7930

123. R. Gehrke, EG\&G Idaho Inc., P. O. Box 1625, 2151 N Blvd., MS-7111, Idaho Falls, ID 83415

124. R. Geimer, SAIC, 545 Shoup Ave., P.O. Box 50697, Idaho Falls, ID 83405-0697

125. J. Gill, James H. Gill \& Associates, 12015 Manchester, St. Louis, MO 63131 
126. R. Gillins, SAIC, 545 Shoup Ave., P.O. Box 50697, Idaho Falls, ID 83405-0697

127. K. Hain, EM-55, U.S. Department of Energy, 1000 Independence Ave., SW, Washington, DC 20585

128. P. Hart, EM-542, U.S. Department of Energy, 1990 Germantown Rd., Trevion II, Germantown, MD 20874-0002

129. J. Helt, Argonne National Laboratory, 9700 S. Cass Avenue, Bldg. 205, Argonne, IL 60439

130. D. Helton, Westinghouse Savannah River Co., P.O. Box 616, Bldg. 773-41 A., Rm. 228, Aiken, SC 29802

131. Dr. E. Holtzscheiter, Savannah River Technology Center, P. O. Box 616, Bldg. 773-A, Aiken, SC 29802

132. Hugh G. Hempill, Morrison Knudsen Corporation, 180 Howard St., San Francisco, CA 94105

133. C. Henke, Focus Environmental, 9050 Executive Park Drive, Suite A-202, Knoxville, TN 37923

134. J. Hillary, EG\&G Idaho, Inc., P. O. Box 1625, Idaho Falls, ID 83415

135. G. Hinshaw, Midwest Research Institute, 425 Volker Blvd., Kansas City, MO 64110

136. D. Hjeresen, AET, Bikini Road, MS-P641, Los Alamos, NM 87545

137. J. Hnat, Vortec Corporation, 3770 Ridge Pike, Collegeville, PA 19426

138. T. Ho, Lamar University, P. O. Box 10053, Beaumont, TX 77710

139. Ms. Susan Hodges, CDIF, Industrial Park, Butte, Montana 59701

140. John Holbrook, Pacific Northwest Laboratory, Battelle Blvd., Richland, WA 99352

141. J. Hunter, Westinghouse Hanford Co., P.O. Box 1970, MS L531, Bldg. 3766, Rm. 14, Richland, WA 99352

142. J. Jacquin, SAIC, 555 Quince Orchard Road, Suite 500, Gaithersburg, MD 20878

143. Ms. C. Jantzen, Westinghouse Savannah River Co., P. O. Box 616, Bldg. 773-A, Aiken, South Carolina 29808

144. Ms. Karen M. Jerome, Westinghouse Savannah River Co., 1995 S. Centennial Ave., Bldg. 4, Aiken, SC 29803

145. P. Jones, BDM Federal, 555 Quince Orchard Road, Suite 400, Gaithersburg, MD 208781437

146. P. Kalb, Brookhaven National Lab, Environmental \& Waste Technology Center, North Railroad Street, Bldg. 830, Upton, NY 11973

147. T. Kan, Lawrence Livermore National Lab, P. O. Box 808, MS-1467, Livermore, CA 94550

148. Ms. Mary Jo Kerr, EG\&G Idaho, P. O. Box 1625, Idaho Falls, ID 83415-2320

149. R. Koenig, Merlin Co./Boulder, Inc., 395 Ridgeview Lane, Boulder CO 80302

150. K. Kostelnik, EG\&G Idaho, Inc., P.O. Box 1625, MS-3930, Idaho Falls, ID 83415-3930

151. D. Kried, Battelle Pacific NW Lab, Battelle Blvd., Richland, WA 99352

152-154. O. Krikorian, L-369, Lawrence Livermore National Lab, P.O. Box 808, Livermore, CA 94550

155. O. Kruger, Westinghouse Hanford Company, 2355 Stevens Dr., Richland, WA 99352

156. Paul Krumrine, Waste Policy Institute, 555 Quince Orchard Rd., Suite 600, Gaithersburg, MD 20878

157. D. Kuchynka, SAIC, 555 Quince Orchard Road, Suite 500, Gaithersburg, MD 20878

158. M. Lankford, EM-552, U.S. Department of Energy, 12800 Middlebrook Road, Trevion II, Germantown, MD 20874

159. C. Lee, EPA Risk Reduction Engineering Laboratory, 26 W. Martin Luther King Blvd., Cincinnati, OH 45268 
160. S. Lein, EM-54, U.S. Department of Energy, 12800 Middlebrook Road, Trevion II, Germantown, MD 20874-1290

161. J. Lightly, University of Utah, Salt Lake City, UT 84112

162. J. Lippold, BDM Federal, 20251 Century Blvd., 4th Floor, Germantown, MD 20874

163. J. Mayberry, SAIC, P.O. Box 50697, Idaho Falls, ID 83405-0697

164. J. McCray, WINCO, P.O. Box 4000, MS-5218, Idaho Falls, ID 83415-4000

165. W. McCulla, Los Alamos National Laboratory, SM 30 Warehouse, Bikini Road, S J-563, Los Alamos, NM 87545

166. J. McFee, IT Corporation, 5301 Central Ave., NE, Albuquerque, NM 87108

167. X. Meng, Center for Environmental Engineering, Stevens Institute of Technology, Hoboken, NJ 07030

168. T. Miller, University of Tennessee, College of Engineering, Knoxville, TN 37996-2010

169. T. Moberg, Westinghouse Hanford Co., P.O. Box 1970, MS-425, Richland, WA 99352-1970

170. Nick Monaco, META-Berger, 814 W. Diamond Ave., Suite 101, Gaithersburg, MD 20878

171. David Monts, DIAL, Mississippi State University, P. O. Box 3574, Mississippi State, MS 39762-3574

172. J. O. Moore, U.S. Department of Energy, P.O. Box 2001, Oak Ridge, TN 37830-8620

173. C. Nagel, Molten Metal Technology, 25 First St., Cambridge, MA 02141

174. R. Nakaoka, Los Alamos National Laboratory, P.O. Box 1663, MS-6517, Los Alamos, NM 87545

175. M. Namar, Office Of Radiation Programs, 401 N. Street, S.W. (ANR-461) Washington, DC 20460

176. David Navarro, Citizen Advisory Board/Stakeholder Input, 7850 Yates St., Westminster, CO 80030

177. Dr. James Navratil, Rust Federal Services, 1597 Cole Blvd., Bldg. 15, Suite 350, Golden, Co 80401-3414

178. J. Newburn, Thermatrix Inc., 3590 N. First Street, Suite 310, San Jose, CA 95134

179. S. Newman, Martin Marietta Energy Systems, Inc., P. O. Box 628, Piketon, OH 45661

180. G. Ordaz, EM-541, U.S. Department of Energy, 12800 Middlebrook Road, Trevion II, Germantown, MD 20874

181. T. Overcamp, Clemson University, 342 Computer Ct., Anderson, SC 29625

182. John Patten, Vortec Corporation, 3770 Ridge Pike, Collegeville, PA 19426

183. Robert Pearson, EG\&G/DOE Rocky Flats, 1282 S. Routt Way, Lakewood, CO 80232

184. R. Peters, Battelle-Pacific Northwest Lab, P.O. Box 999, MS P7-41, Richland, WA 99352

185. H. Pham, Air Products and Chemicals Inc., 7201 Hamilton Boulevard, Allentown, PA 18195-1501

186. B. Place, Westinghouse Hanford Co., P. O. Box 1970, MS-H5-33, Richland, WA 99352

187. R. Price, Duratek, 8955 Guilford Rd., Suite 200, Columbia, MD 21046

188. G. Reed, University of Tennessee, College of Engineering, Knoxville, TN 37996-2010

189. Ray S. Richards, Associated Technical Consultants, 2375 Dorr St., Suite I, Toledo, $\mathrm{OH}$ 43607-3406

190. W. Ross, Battelle-Pacific Northwest Lab, P.O. Box 999, MS P7-41, Richland, WA 99352

191. Ms. T. Ryan, ICF Kaiser, P. O. Box 888, MSIN E6-64, Richland, WA 99352

192. A. F. Sarofim, Department of Chemical Engineering, 66-153 MIT, Cambridge, MA 02139

193. Max P. Schlienger, Retech Inc., P. O. Box 997, Uriah, CA 95482

194. R. Schumacker, Westinghouse Savannah River Co., SRTC, P.O. Box 616, Bldg. 773-42A, Aiken, SC 29808 
195. B. Schutte, EM-54, U.S. Department of Energy, 12800 Middlebrook Road, Trevion II, Germantown, MD 20874-1290

196. B. Schwinkendorf, BDM Federal, 1801 Randolph Rd., SE, Albuquerque, NM 87106

197. W. Searles, Associated Technical Consultants, 2375 Dorr St., Suite I, Toledo, OH 43607 3406

198. R. Seeker, EER Corp., 18 Mason, Irvine, CA 92718

199. G. Sevigny, Battelle-Pacific Northwest Lab, P.O. Box 999, MSIN P7-42A, Aiken, SC 29808

200. M. Shupe, EM-541, U.S. Department of Energy, Trevion II, Room 440, 19901

Germantown Road, Germantown, MD 20874-1290

201. D. Singh, Argonne National Lab, 9700 South Cass Ave., Bldg. 212, Rm. G-233, Argonne, IL 60439

202. S. Slate, Battelle Pacific Northwest Laboratory, 902 Battelle Blvd., P.O. Box 999, KI-25, Richland, WA 99352

203. E. F. Snow, Plasma Energy Applied Technology, Inc., 4914 Moores Mill Road, Chase Industrial Park, Huntsville, AL 35811

204. G. Sprenger, Waste Project, EG\&G-Rocky Flats Plant, P.O. Box 464, Bldg. 750, Golden, CO $80402-0464$

205. M. Springer, Plasma Energy Applied Technology Inc., 4914 Moores Mill Road, Chase Industrial Park, Huntsville, $\mathrm{AL} 35811$

206. S. Stein, Battelle Seattle Research Center, 4000 NE 41st, Seattle, WA 98105-5428

207. M. Stevenson, SAIC, 545 Shoup Ave., Idaho Falls, ID 83402-3575

208. P. Sydenticker, BDM Federal, 20251 Century Blvd., 4th Floor, Germantown, MD 20874

209. T. Timmerman, Mason \& Hanger, P. O. Box 30020, T-9050, Amarillo, TX 79177

210. T. Uhlmeyer, MD-Ferguson Co., 7295 Highway 94 South, St Charles, MO 63304

211. R. VanKonynenburg, Lawrence Livermore National Laboratory, P.O. Box 808, L352, Livermore, CA 94550

212. J. Vavruska, Equinox, Ltd., 872 Don Cubero Ave., Santa Fe, NM 87501

213. C. Ward, Westinghouse Savannah River, P. O. Box 616, Building 773-A, D-1134, Aiken, SC 29808

214. S. Warren, EM-442, U.S. Department of Energy, 12800 Middlebrook Road, Trevion II, Germantown, MD 20874-1290

215. L. Waterland, Accurex Environmental Corp., 555 Clude Ave., P. O. Box 7044, Mountain View, CA 94039

216. K. Whittle, Electropyrolysis, Inc., 996 Old Eagel School Road, Wayne, PA 19087

217. J. Witzeman, P.O. Box 398704, 7400 Williey Road, Fernald, OH 45030

218. S. Wolf, U.S. Department of Energy, Trevion II, 19901 Germantown Road, Germantown, MD 20874

219. W. Wolfe, SAIC, 545 Shoup Ave., P.O. Box 50697, Idaho Falls, ID 83405-0697

220. R. Womack, Retech, Inc., P.O. Box 997, 100 Henry Station Road, Uriah, CA 95482-0997

221. John J. Wong, Westinghouse Hanford Co., P. O. Box 1970, B2-24, Richland, WA 99352

222. M. Zenkowich, EM-323, U.S. Department of Energy, 12800 Middlebrook Road, Germantown, MD 20874

223. Office of Assistant Manager, Energy Research and Development, DOE-OR, P.O. Box 2001, Oak Ridge, TN, 37831

224 225. Office of Scientific and Technical Information, P.O. Box 62, Oak Ridge, TN 37831 

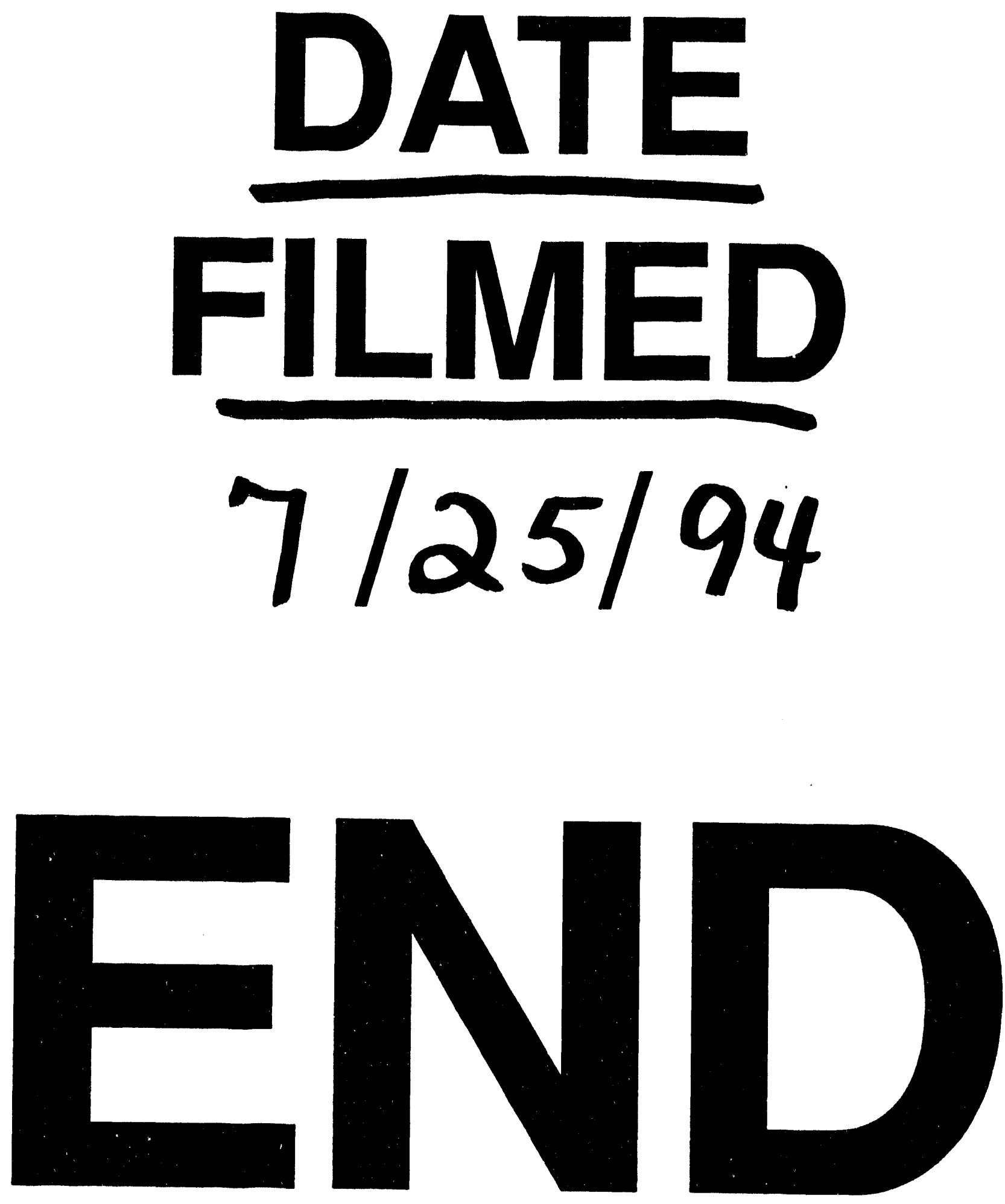
